\title{
Article \\ The Impact of ESG Management on Investment Decision: Institutional Investors' Perceptions of Country-Specific ESG Criteria
}

\author{
So Ra Park ${ }^{1}$ and Jae Young Jang ${ }^{2, *(D)}$ \\ 1 Department of Tourism Management, Cheju Halla University, Jeju-si 63092, Korea; doorae0207@chu.ac.kr \\ 2 Department of International Business and Accountancy, Cheju Halla University, Jeju-si 63092, Korea \\ * Correspondence: jyjang@chu.ac.kr
}

check for

updates

Citation: Park, So Ra, and Jae Young Jang. 2021. The Impact of ESG

Management on Investment Decision: Institutional Investors' Perceptions of Country-Specific ESG Criteria. International Journal of Financial Studies 9: 48. https://doi.org/ 10.3390/ijfs9030048

Academic Editor:

Sorinel Capusneanu

Received: 26 July 2021

Accepted: 3 September 2021

Published: 9 September 2021

Publisher's Note: MDPI stays neutral with regard to jurisdictional claims in published maps and institutional affiliations.

\begin{abstract}
Existing global ESG models are limited in terms of applicability and predictability, especially in countries with an unstable environment. On the other hand, utilizing internally made or privately sourced ESG models have caused issues relating to generalizability, comparability, and continuity. In our research, we present an ESG framework that is specific to South Korea, which has both global and country-specific factors in all three categories. The AHP model is used to determine how the three categories' materiality would be viewed by institutional investors as well as how country-specific factors rank against global factors. The results of this study show that institutional investors place more importance on environmental and governance factors compared to social factors. Factors including shareholders' rights, pollution and waste, greenhouse gas emissions, and risk and opportunity management are found to have greater influences on investors' investment decisions. In addition, it was confirmed that both of the country-specific variables for South Korea, partnership with subcontractor and CEO reputation, have a significant influence on investment decisions. By having the ESG model validated by institutional investors, who are the main users of ESG disclosures of corporations, our methodology of presenting a country-specific model can be benchmarked by studies on other emerging markets with a variety of country-level specificities.
\end{abstract}

Keywords: ESG management; ESG investment; Korean specific ESG model; partnership with subcontractor; CEO reputation; institutional investor; analytical hierarchy process (AHP)

\section{Introduction}

This study aims to identify how ESG elements are considered and how important these factors are to investors in making investment decisions. ESG management has become a major social issue internationally and domestically. Many investors are searching for companies that fit their ESG criteria, and regulators in many countries are coming up with new regulations or legislation. Consulting firms and private institutions are distributing ESG models that reflect some characteristics of individual countries. However, there is no universal ESG framework agreed upon amongst stakeholders, and academic research on country-specific ESG models are so far lacking.

This study proposes a country-specific ESG model for South Korea and seeks to find a consensus amongst institutional investors. The findings of this study can be used in corporate ESG management activities, investors' investment decisions, and governmental bodies' regulatory policy formulation.

ESG is becoming a must-have goal for sustainability. Indeed, European sovereign wealth funds and pension funds in countries such as the UK, Sweden, and France are requiring that companies disclose ESG-related information. In addition, funds have been moving rapidly into the ESG sector in recent years. The UN PRI reported that assets under management (AUM) in the ESG sector increased from \$6 trillion in 2006 to \$104 trillion in 2020 (UNPRI 2021). 
However, much preliminary work and regulatory enforcement is needed to build a reliable framework with solid social acceptance that can lead to more widespread uses of ESG information. The main constraining factors are as follows: (1) Companies in emerging economies such as South Korea lack a reliable ESG model, (2) Current ESG factors do not take into account country-specific and/or industry-specific management environments. (3) As can be seen in Figure 1, ESG evaluation scores vary significantly by the provider of ESG information (OECD 2020). For example, Nextera Energy, which is a company in the utility industry, was rated by five different information providers, and the difference between the lowest and the highest ESG score was close to 60 points. There are several reasons for this, but the main reasons are that each provider analyzes different factors, uses a different methodology, and applies different weightings for each factor. Significant differences in ESG ratings between providers may impede ESG-related management and reduce the impact of ESG ratings on investment portfolios (Boffo and Patalano 2020).

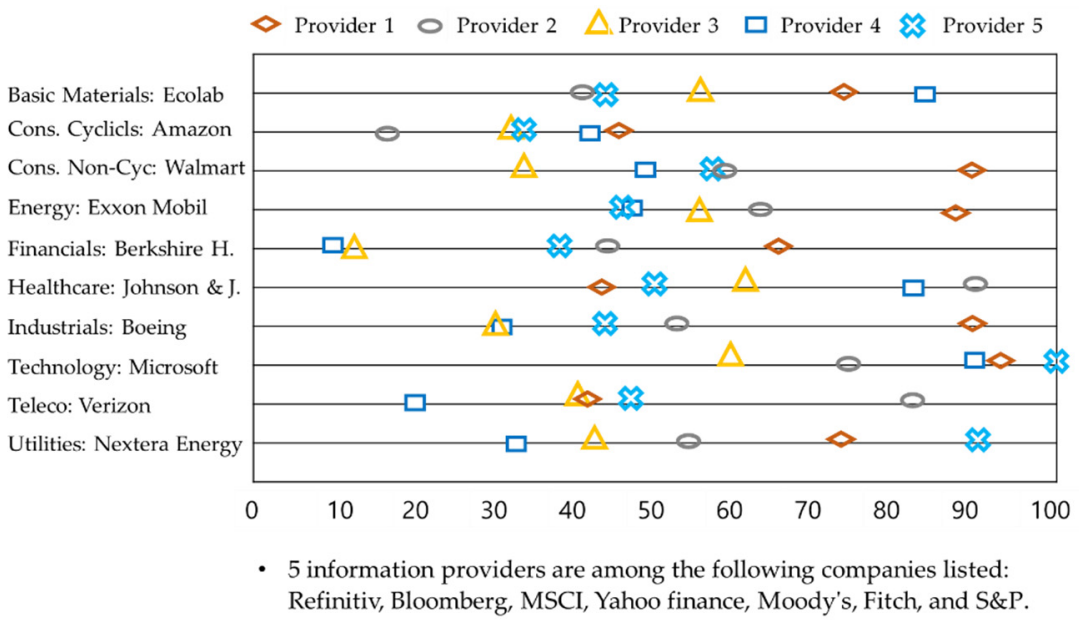

Figure 1. ESG ratings of companies from diverse industries from five information providers.

ESG activities and explicit reporting on them can provide another means of addressing social issues while improving corporate value. ESG efforts for a sustainable society need concrete actions, and the first step is to develop a well-established model that can be sympathized by a variety of stakeholders. To achieve this, it is necessary to build an appropriate ESG model for each country that reflects each country's economic and social environment.

The aim of this study is to create an ESG model that is specific to the Korean business environment and to identify the relative weights of factors that reflect investors' views. South Korea is particularly interesting because it contains leading qualities of advanced economies, but the business environment is similar to those of emerging countries (Welling 2020; Jang and Park 2019). South Korea is still classified as an emerging country by international rating agencies. However, as of August 2020, Korea belongs in the G10 in terms of GDP, has the 8th largest foreign exchange reserve in the world with $\$ 45.86$ billion, and the financial market is well-developed and competitive (Jang and Atukeren 2019). In addition, South Korea's national credit rating is AA by S\&P and Aa2 by Moody's, which is two notches higher than those of Japan and China. Korean companies are ranked 5th in the world, with 15 companies on the Fortune 500 as of 2020. South Korea is also considered to be one of the countries where ESG is managed well. In its ESG evaluation report of 144 countries around the world, Moody's (2021) concluded that 11 countries including Korea, Germany, and Switzerland had the highest ESG Credit Impact Scores (CIS).

On the other hand, South Korea has been experiencing side effects of very fast economic growth over the past few decades. Its economic structure is heavily dependent on chaebol companies, there has been a rapid decline in the labor force due to an aging population, and there are social conflicts due to economic inequality. 
To accommodate for South Korea's specificities, we included two country-specific factors in the ESG model: CEO reputation and partnership with subcontractors (this is discussed in more detail in Section 4.1). These South Korean factors are frequently discussed, as they represent the past and present of the Korean economy and society. Korean stocks are undervalued compared to those of other emerging and developed countries in terms of price-to-book ratio (PBR). It has been established that the main causes of the so-called Korea discount are (1) inefficiencies and lack of transparency in corporate governance, and (2) corporate culture that fails to fulfill its social responsibilities (Aghion et al. 2021). These are directly or indirectly related to the practice of inheritance of ownership within chaebol families and large corporations' unfair treatment of subcontractors.

The development of the Korean ESG model has implications for both academia and practice and will be considered an exemplary case for other emerging markets.

We intent to contribute to the standardization of the ESG framework by taking the following systematic steps: (1) identifying universally important factors constituting the ESG framework by extracting common factors from globally leading ESG information providers, along with detailed literature reviews; (2) adding to the framework crucial factors that reflect specificities of South Korea; and (3) building a hierarchical structure with the variables in the first two steps. With this proposed framework, the relative importance of each variable was analyzed with the expert opinions. This framework can objectively evaluate a company's ESG activities and help companies deploy their ESG efforts. In addition, this study confirms that the Korean-specific variables used in this ESG model are recognized by institutional investors as key criteria for their investment decision.

The remainder of the paper is organized as follows. Section 2 provides a review of the literature on ESG. Section 3 states the methodological framework of the study, and Section 4 describes the hierarchical structure. Section 5 reports the results of analysis, and Section 6 concludes with implications.

\section{Literature Review}

The concept of sustainable development goes back to the Brundtland Report of 1887, also known as Our Common Future, which defines sustainable development as "development that meets the needs of the present without compromising the ability of future generations to meet their own needs." Sustainable Development Goals (SDG) consist of 17 goals and 169 targets. These goals are divided into various categories as follows: social development (five goals), environmental sustainability (seven goals) and economic growth (two goals), along with poverty (two goals), and global partnership (one goal). The Paris Agreement of 2015 is based on a unanimous agreement between 195 nations to reduce greenhouse gas (GHG) emissions. The long-term goal of this agreement was to achieve a balance between GHG emission levels and the earth's absorption level by the year 2050 by keeping the temperature increase to below $2{ }^{\circ} \mathrm{C}$ above pre-industrial levels (preferably $1.5^{\circ} \mathrm{C}$ ).

Corporate ESG disclosures report on how a business carries out its activities in the areas of environment, social, and governance and is tangent with SDGs and the Paris Agreement. As a result, many ESG frameworks are designed with SDGs and the Paris Agreement in mind. To take an example, Stakeholder Capitalism Metric (World Economic Forum 2020) relates each of the pillars of their ESG framework with SDGs. For instance, the governance pillar relates to Goal 12 (Responsible consumption and production), Goal 16 (Peace, justice, and strong institutions), and Goal 17 (Partnerships for the goals). Similarly, the climate change category of the planet pillar uses the Paris-aligned GHG emission targets as a guiding metric.

The UN is the biggest force in legislation of ESG disclosure and corporate ESG adoption. In 2019, the UN PRI announced that PRI signatories are mandated to disclose the PRI climate indicators on four categories: governance, strategy, risk management, and metrics. The UN PRI was the first major organization to include ESG information in their reports as a mandatory requirement. The EU was the first economic community to introduce ESG requirements, by implementing the EU Directive on Non-Financial and Diversity 
Information. The initial EU directive only applied to sizable companies with more than 500 employees, as well as at least EUR 30 million in assets, and / or net sales of at least EUR 400 million. Furthermore, in April 2021, the EU proposed a revision to the Directive, the Corporate Sustainability Reporting Directive, which applies to all large and listed companies.

Corporate ESG adoption has multiple determinants and expected outcomes. First, management could consider adopting ESG as a strategic decision. A firm's efforts in sustainability can improve firm value and promote sustainability (Freeman 1984), bring differentiation and cost savings (Porter et al. 2019), have positive effects on employees' work engagement (Agarwal et al. 2012), and improve the productive behavior of employees (Park 2020) and customer loyalty (Kim and Park 2017).

Secondly, adopting ESG can help with risk/opportunity management, which can in turn benefit management, employees, participants in the supply chain, and customers. Corruption threatens the survival of newly established firms (Nam et al. 2020) and can have a significant negative impact on profitability and stock prices (Thakur et al. 2019). Dealing with risks can be a proactive approach to improving business sustainability (Jo and Na 2012). Management cost are reduced when it can solve or prevent possible occurrences of trouble (Swanson 1999). Risk management should cover the area of corporate reputation as well. News releases about illegal activities have had negative impacts on companies' profits, even more so than operating crimes (Song and Han 2017). De Franco (2020) investigated the impact of ESG-related controversies on the performance of stocks and portfolios and found that portfolios with severe ESG controversies or downgraded ESGs performed relatively poorly. The prevailing view of recent research is that highly sustainable companies have relatively low downside risks and are more resilient to turbulence. Hoepner et al. (2019) found evidence that firms' participation in ESG reduces firms' downside risk. Ilhan et al. (2021) argued that companies with poor ESG profiles due to high carbon emissions have higher tail risk. Studies covering the period of the global financial crisis have shown that both financial and non-financial U.S. companies with high ESG ratings outperformed others (Cornett et al. 2016).

Thirdly, regardless of whether a company is adopting ESG as a part of legal or regulatory compliance, it is the company's duty as a participant of the society. Adopting ESG disclosures alone would not make the company ethical, but it will make the company more ethically selective when it makes relevant decisions. By assessing corporate practices, ESG rating agencies and other financial lenders can be considered changing agents themselves (Escrig-Olmedo et al. 2019).

Lastly and most importantly, corporate adoption of ESG can be beneficial to stakeholders of the company. Investing in ESG is stimulating mainstream interest from institutional investors for two reasons. First, ESG investing actively promotes ethical investment practices. Secondly, ESG investments are being considered as a means to improve the performance of managed portfolios, increase returns, and reduce portfolio risk (Broadstock et al. 2021).

For shareholders, they would expect the corporation to have better economic performance and sustainability in the future. Matos et al. (2020) found that sustainable firms have a greater chance of stable dividend payouts. Sustainable companies have better long-term relationships with other stakeholders other than shareholders as well. A number of studies in the existing literature suggest that investment in companies with good ESG practices have a higher return on investment, and exemplary ESG management in companies can proactively prevent sudden shocks to cash flows (Lee et al. 2013). Friede et al. (2015) reviewed ESG/SRI studies and found a significant positive relationship between ESG performance and financial performance.

The three pillars of ESG have been studied regarding their performance outcomes. Research on investments in environment-conscious firms have shown conflicting results. Reduction in $\mathrm{CO}_{2}$ had no financial benefits for firms, especially during the Great Recession (Gallego-Alvarez and Segura 2015). However, according to a study that analyzed over 140 Australian non-financial firms, environmentally-oriented firms were found to have 
significantly higher profits and market shares (Menguc and Oanne 2005). In addition, Hart and Ahuja (1996) reported that emission reductions had a positive relationship with the return on assets (ROA) of firms listed in the Standard and Poor's 500. In terms of the social pillar, most previous studies have shown that socially conscious companies perform better financially (Allouche and Laroche 2005; Becchetti et al. 2015). In a study by the CFA Institute on ESG adoption in the Americas, it was found that social issues have more impact compared to environmental and governance issues on areas such as sovereign debt to yields in the U.S. and corporate bond yields/spreads (CFA Institute 2018). However, some also argued that social efforts related to stakeholders produced no immediate and direct impact on firms' profitability (Brulhart et al. 2019; Ghassim and Boger 2019). In terms of governance, the composition of a company's decision-making body was found to have impacts on its financial performance. To take an example, gender diversity had a positive influence on firms' performance (Noland et al. 2016), enhanced CSR, and reduced corporate social irresponsibility (Boukattaya and Omri 2021). The financial performance of firms was positively related with the size of their board (Rehman et al. 2021) and management expertise (Gandhi et al. 2015). Having politically independent CEOs in Korean state-owned companies positively influenced customer satisfaction (Yu 2013).

Looking at the individual elements of each pillar, not all elements are equally important. Studies on the materiality of ESG factors have looked at how much impact each factor has on corporate performance. According to Amel-Zadeh and Serafeim (2018), the performance of ESG portfolios is based on investors' choice of ESG criteria, rather than whether or not the investor is dealing with ESG product or not. In addition, materiality is different for each country, industry, and company. Materiality in industry-level and company-level contexts has been studied. Companies that focus on industry-specific materiality issues have been shown to perform better (Eccles and Serafeim 2013; Khan et al. 2017). A survey of 126 financial analysts that used ESG information for portfolio construction and management found that they did more analysis on ESG performance on the company level rather than industry level (Van Duuren et al. 2016). While there has been some academic research focusing on ESG-related country risk management, only a few papers have looked at the country-specific materiality of ESG framework factors. Sherwood and Pollard (2017) discussed how ESG portfolios' performance in countries such as South Korea and Russia should factor in country-related factors such as the level of ESG investment opportunities and the centrality of the economy on several Chaebol companies.

There are some papers that look at category-level materiality. Weights for different categories are also found to be dependent on industry characteristics. Bender et al. (2018) found that the relative importance of environmental, social, and governance factors vary by sector and explained how the real estate sector would give $100 \%$ weighting to the environmental category. Industries such as materials, industrials, consumer discretionary, and consumer staples industries would allocate equal weight to each of the factors due to the specificities of the industries. In addition, weighing on categories can change over time. Nagy et al. (2020) showed that the weight of the governance factor increased the most from $19 \%$ in 2007 , to $27 \%$ in 2019 , and finally to $31 \%$ in 2020 . From their short-term analysis, it was found that negative events related to the governance factor were reflected in the stock prices of the top-tier and bottom-tier companies the most quickly, which were followed by events relating to social and then environmental factors. Issues related to governance are generally sector-neutral, but issues related to social and environment factors are highly sector-relevant. Refinitiv gives $43 \%, 31 \%$, and $25 \%$ of weights to environmental, social, and governance factors, respectively (Refinitiv 2021). For example, MSCI research showed that across industries, the average weight of environmental factors was $30 \%$, while that of social factors was 39\%, and that of governance factors was 31\% (Nagy et al. 2020). However, according to an OECD report (Boffo and Patalano 2020), there is no permanent pattern that any one of the three pillars are the best predictor of overall corporate performance. Different ESG rating providers have different ways of measuring the performance of environmental, social, and governance categories. Such performance results would be used for 
weighting the categories and the respective subcategorical factors. Therefore, it is natural to assume that weighting to ESG categories and their subcategorical factors should be varied not only by the industry and rating providers but also by countries with different environmental, economic, geographic, and political characteristics.

International and national efforts are being made to have ESG reporting as a standard practice in an attempt to influence corporations' environmental and social decisions. In 2019, the UN PRI announced that PRI signatories are mandated to disclose PRI climate indicators on four categories comprised of governance, strategy, risk management, and metrics. The UN PRI is the first major organization to make it a mandatory requirement to include ESG information in their reports. In 2016, the EU as the first economic community introduced the EU Directive on Non-Financial and Diversity Information. The initial EU directive only applied to sizable companies with more than 500 employees as well as with at least EUR 30 million in assets and/or net sales of EUR 400 million or more. In April 2021, the EU proposed the revised version of the Directive, the Corporate Sustainability Reporting Directive, which is applicable to all large and listed companies.

To uphold soft and hard laws on ESG reporting, there should be objective and reliable ESG indicators for companies to utilize. In 1997, the Global Reporting Initiative (GRI), a non-governmental organization for corporations' sustainability reporting guidelines, was founded. In 2000, it announced the GRI Standard in 2000, which has been most recently updated in 2016. The GRI standard is used as one of the main frameworks in reporting the sustainability and ESG status of corporations and institutions. In addition, the Taskforce on Climate-Related Financial Disclosures (TCFD) was created by the Financial Stability Board. In 2017, the TCFD recommended that firms report core ESG elements including governance, strategy, risk management, and metrics and targets in their major financial filings.

There are early adopters and laggards with regard to ESG disclosures. Adoption, legislation, and the enforcement of ESG laws and regulations are different in every region and country. The European Union has proposed the Corporate Sustainability Reporting Directive. When enacted, it will require all large and listed companies to disclose their ESG reports, which will also need to be audited. All companies that want to do business with EU companies or trade in EU regions need to be ready for this revised directive. Around the globe, regulatory pressure for sustainable management is increasing in emerging markets as well. Global investors often request ESG reports to be produced for their investment decisions. In addition, MNCs often verify that their suppliers, many of whom operate in emerging countries, are ESG compliant as well (due diligence) (KCGS 2012). As a result, there is a strong need for a global framework that will accommodate the specificities of different countries.

In South Korea, research on ESG along with CSR began in the 2010s. Existing studies mainly performed analysis using the KEJI index of the Economic Justice Institute, as well as the ESG evaluation criteria and ratings of the Korea Corporate Governance Service. The main direction of the existing study was quantitative analysis of the correlation between ESG/CSR activities of companies and corporate value (Kim and Kim 2018; Yang and Yoon 2015), cost of capital (Choi 2015; Kim and Jung 2018), the deterrent effect of tax evasion (Lee 2018), efficiency of the company's new investment (Choi 2018), and accounting transparency (Park and Lee 2017). In addition, other studies have shown that the higher the stake of the largest shareholder, the lower the ESG level; and the higher the ratio of outside directors and the stake of foreign investors, the higher the ESG activity (Kim and Jung 2012). Similar results were also found in studies on Chinese companies (Park 2017).

\section{Research Methodology and Materials}

To present a country-specific ESG model, we will have E, S, and G as the main categories and select factors that will be subcategories of E, S, and G pillars. Factors, the building blocks of ESG models, are typically selected using a three-step process (Eccles and Serafeim 2013). First, there should evidence of interests. Abundant litera- 
ture should be visited and keywords from the documents drawn. Second, evidence of financial significance should be given. Third, adjustments should be made as the significance of a certain issue arises. Changes to the set of ESG factors should be made when necessary. The third step would be only performed after the initial working model is built and endured some events; therefore, in our research, we will build the model using only the first two steps.

To evaluate and assign weights to key factors, there are three widely used corporate social performance schemes (Chen and Delmas 2011; Garefalakis and Dimitras 2020): (1) equal weight for all, (2) weights driven by expert opinion, and (3) weight derived from survey (Chen and Delmas 2011). To assign weights to ESG categories and subcategories, surveys from ESG experts and relevant stakeholders are often used. The AHP method is a measure that relies heavily on expert judgment and assigns a proportion of each alternative reflecting importance.

This paper conducts research using the Analytical Hierarchy Process (AHP), which is presented by Saaty et al. (1980). The AHP is a multi-criteria decision-making technique based on hierarchies that uses eigenvalue and eigenvector methods to determine the relative weights of criteria and alternatives. This methodology is useful in organizing problems with multiple criteria hierarchically and coming up with a decision based on quantitative and qualitative analysis (Saaty 2003).

\subsection{Decision Framework: Application of the AHP Method}

AHP is primarily used for decision making in complex scenarios in which people make decisions together when human perceptions, judgments, and consequences have long-term repercussions (Bhushan and Raj 2004). Bias affects decision making without the decision maker's awareness. AHP can reduce decision bias by listening to all possible opinions and constructing decisions in a way that actively builds consensus among stakeholders. The validated results can lead to better decisions fully supported by stakeholders. AHP's strengths include: (i) usability, (ii) easy and rational approach, (iii) breaking the problem into smaller steps, (iv) not requiring analysis of secondary data to have research results with implications.

The AHP is an appropriate research method because this study has to address a number of elements from multiple perspectives. In particular, in our research context, utilizing AHP can be useful in bringing institutional investors' often biased opinions together, in coming up with consensus on what ESG criteria companies need to focus more heavily, and in analyzing the limited number of institutional investors' qualitative data. This study conducts the analysis in a five-step procedure as follows:

- $\quad$ Step 1: Identify ESG factors used by the existing literature and major ESG information providers, and point out limitations and problems of existing models. This has already been investigated in this literature review section, but it will be further explored in Section 3.2.

- Step 2: Analyze the factors and construct a hierarchy of decision-making factors.

- Step 3: Prepare questionnaires for pairwise comparisons, distribute them to experts, and collect responses.

- $\quad$ Step 4: Check for consistency.

- Step 5: Prioritize and evaluate it.

The essence of the AHP analysis method is to construct a matrix representing the relative values of a set of attributes. Among the various criteria of ESG, which factors have a relatively significant influence on investment decisions? Respondents are asked to choose which factors are more or less important. Each of these judgments is assigned a number on the scale. A 9-point scale was used in this paper. In this article, a 9-point scale was used with ' 1 ' in the center (equally important), ' 5 ' on the leftmost (A is absolutely more important), and ' 5 ' on the rightmost ( $\mathrm{B}$ is absolutely more important). If attribute $\mathrm{A}$ is absolutely more important than attribute B, then B must be absolutely less important than A and evaluates to $1 / 9$. The next step is to compute a list of relative weights associated 
with that problem. The final step is to calculate the consistency ratio (CR) to measure how consistent the judgments are compared to a large sample of purely random judgments. If the CR is much in excess of 0.1 , the judgment is unreliable, because it is too close to randomness and the exercise is worthless or has to be repeated.

The AHP method can be described in terms of matrices and vectors. Consider $n$ elements to be compared, $C_{1} \ldots C_{n}$, and denote the relative 'weight' of $C_{i}$ with respect to $C_{j}$ by $a_{i j}$ and form a square matrix $A=\left(a_{i j}\right)$ of order $n$ with the constraints that $\mathrm{a}_{\mathrm{ij}}=1 / \mathrm{a}_{\mathrm{ji}}$, for $\mathrm{i} \neq \mathrm{j}$, and $\mathrm{a}_{\mathrm{ii}}=1$, all $\mathrm{i}$. The weights are consistent if they are transitive, that is, $a_{k}=a_{i} a_{j k}$ for all $i, j$, and $k$. Such a matrix might exist if the $a_{i j}$ values are calculated from exactly measured data. Then, find a vector $\omega$ of order $\mathrm{n}$ such that $\mathrm{A}_{\omega}=\lambda_{\omega}$. For such a matrix, $\omega$ is said to be an eigenvector and $\lambda$ is an eigenvalue. For a consistent matrix, $\lambda=n$. For matrices involving human judgement, the condition $\mathrm{a}_{\mathrm{ik}}=\mathrm{a}_{\mathrm{ij}} \mathrm{a}_{\mathrm{jk}}$ does not hold, as human judgements are inconsistent to a greater or lesser degree. In such a case, the $\omega$ vector satisfies the equation $A_{\omega}=\lambda_{\max \omega}$ and $\lambda_{\max } \geq \mathrm{n}$. The difference, if any, between $\lambda_{\max }$ and $\mathrm{n}$ is an indication of the inconsistency of the judgements. If $\lambda_{\max }=\mathrm{n}$, then the judgements have turned out to be consistent. The consistency index can be calculated from $\left(\lambda_{\max }-\mathrm{n}\right) /(\mathrm{n}-1)$. The consistency ratio is calculated by dividing the consistency index for the set of judgments by the Index for the corresponding random matrix. Saaty suggests that if that ratio exceeds 0.1 , the set of judgments may be too inconsistent to be reliable. In practice, CRs of more than 0.1 sometimes have to be accepted. A CR of 0 means that the judgements are perfectly consistent.

\subsection{Derivation of Components}

As discussed in the literature study, there is a strong need to have a consensus on a standardized ESG framework. The diversity of models makes standardization of the ESG framework difficult. Therefore, before applying ESG specificities by country, industry, and company, the common criteria to measure ESG-related non-financial factors need to be firmly established first. For this research, we selected five representative ESG frameworks. Table 1 summarizes the elements constituting the ESG of the five most reliable ESG information providers: Stakeholder Capitalism Metric (World Economic Forum 2020), SASB (2020), Refinitiv (2021), MSCI (2020), and S\&P Global (2021). All five ESG information providers are chosen due to their ESG leadership (Stakeholder Capitalism Metric), standardization (SASB), and recognition within the industry (Refinitiv, MSCI, and S\&P Global). The International Business Council (IBC) published Stakeholder Capitalism Metric after the 2020 annual meeting of the World Economic Forum (WEF) developed by four major accounting firms: Deloitte, EY, KPMG, and PwC. The Metric utilizes the guidelines of the world's leading ESG standard providers, including GRI (Global Reporting Initiative), TCFD (Task Force on Climate-related Disclosures), SASB, OECD Oslo manual, UN guiding principle, and others. Another information provider, SASB, is one of the reputed ESG standard bodies along with GRI, CDP (formerly the Carbon Disclosure Project), and IIRC (Hazelton and Perkiss 2018). S\&P Global, MCSI, and Refinitiv are the most referenced worldwide informants in terms of economic and financial indices and ratings (SustainAbility 2020). These five representative ESG frameworks have factors capturing the same aspects of ESG, and the shared factors should be the core of ESG.

Driving commonality from the selected framework requires setting a new categorization (E, S, and G, taking the most general form); then, factors from the existing categories are needed to be recategorized into. Shareholder Capitalism Metric has four pillars: principles of governance, planet (representing E), people (representing social), and prosperity. The prosperity category's sub-criteria are recategorized in E, S, or G based on their themes. For example, employment and wealth generation is reclassified into $S$, since it covers rate of employment, economic contribution, and financial contribution to the society. The SASB framework has environment, social capital, human capital, business model and innovation, and leadership and governance as its major categories. Business model and innovation is recategorized into E and G based on their relevance with E, S, or G. Refinitiv has 4 major 
categories: E, S, G, and ESG controversies. ESG controversies discusses legal, ethical, and reputational exposure the company has on $\mathrm{E}, \mathrm{S}$, and $\mathrm{G}$, which are recategorized under $\mathrm{E}, \mathrm{S}$, and G. S\&P Global has economic, environmental, and social criteria. The sub-criteria of economic dimensions are reclassified under $\mathrm{G}$ and $\mathrm{S}$.

Table 1. ESG components of the five information providers.

\begin{tabular}{|c|c|c|c|c|c|}
\hline & $\begin{array}{c}\text { Stakeholder } \\
\text { Capitalism Matric }\end{array}$ & SASB & Refinitiv & MSCI & S\&P Global \\
\hline $\mathrm{E}$ & $\begin{array}{c}\text { - Freshwater } \\
\text { availability } \\
\text { - Climate change } \\
\text { - Air pollution } \\
\text { - Nature loss } \\
\text { - Innovation of better } \\
\text { products and } \\
\text { services }\end{array}$ & $\begin{array}{l}\text { - Energy management } \\
\text { - Water management } \\
\text { - GHG emissions } \\
\text { - Climate change } \\
\text { - Waste and hazardous } \\
\text { materials } \\
\text { - Product design and } \\
\text { lifecycle management } \\
\text { - Ecological damage } \\
\text { - Material sourcing }\end{array}$ & $\begin{array}{l}\text { - Resource use } \\
\text { - Emission } \\
\text { - Innovative } \\
\text { environmental } \\
\text { strategy } \\
\text { - Controversies on } \\
\text { environmental } \\
\text { issues }\end{array}$ & $\begin{array}{c}\text { - Natural resources } \\
\text { depletion } \\
\text { - Climate change } \\
\text { - Pollution and } \\
\text { waste } \\
\text { - Environmental } \\
\text { strategy }\end{array}$ & $\begin{array}{c}\text { - Operational } \\
\text { eco-efficiency } \\
\text { - Climate strategy } \\
\text { - Environmental reporting } \\
\text { - Environmental policy } \\
\text { and management system }\end{array}$ \\
\hline $\mathrm{S}$ & $\begin{array}{c}\text { - Dignity and } \\
\text { equality } \\
\text { - Health and } \\
\text { well-being } \\
\text { - Skills for the future } \\
\text { - Employment and } \\
\text { wealth generation } \\
\text { - Community and } \\
\text { social support }\end{array}$ & $\begin{array}{l}\text { - Human rights and } \\
\text { community relations } \\
\text { - Human capital } \\
\text { - Product quality, safety } \\
\text { selling practices, and } \\
\text { product labeling } \\
\text { - Customer privacy } \\
\text { - Data security } \\
\text { - Customer welfare } \\
\text { - Access and affordability }\end{array}$ & $\begin{array}{l}\text { - Human rights } \\
\text { - Community } \\
\text { - Workforce } \\
\text { - Product } \\
\text { responsibility } \\
\text { - Controversies on } \\
\text { social issues }\end{array}$ & $\begin{array}{c}\text { - Product, human } \\
\text { capital } \\
\text { - Social } \\
\text { opportunities } \\
\text { - Satisfaction of } \\
\text { customer, } \\
\text { employee, supplier, } \\
\text { and other } \\
\text { stakeholders }\end{array}$ & $\begin{array}{c}\text { - Human rights } \\
\text { - Corporate citizenship } \\
\text { and philanthropy } \\
\text { - Labor practice indicator } \\
\text { - Talent attraction and } \\
\text { retention } \\
\text { - Customer relationship } \\
\text { management } \\
\text { - Information security and } \\
\text { system availability } \\
\text { - Policy influence } \\
\text { - Social reporting }\end{array}$ \\
\hline G & $\begin{array}{l}\text { - Ethical behavior } \\
\text { - Governing purpose } \\
\text { - Risk and } \\
\text { opportunity } \\
\text { oversight } \\
\text { - Stakeholder } \\
\text { engagement } \\
\text { - Quality of } \\
\text { governance body }\end{array}$ & $\begin{array}{c}\text { - Business ethics } \\
\text { - Business model resilience } \\
\text { - Management of the legal } \\
\text { and regulatory } \\
\text { environment } \\
\text { - Supply chain } \\
\text { management } \\
\text { - Risk (critical incident and } \\
\text { systemic) management }\end{array}$ & $\begin{array}{c}\text { - Management } \\
\text { structure and } \\
\text { compensation } \\
\text { - ESG strategy and } \\
\text { reporting } \\
\text { - Shareholder } \\
\text { rights } \\
\text { - Controversies on } \\
\text { governance issues }\end{array}$ & $\begin{array}{l}\text { - Corporate } \\
\text { behavior } \\
\text { - Corporate } \\
\text { governance }\end{array}$ & $\begin{array}{c}\text { - Codes of business } \\
\text { conduct } \\
\text { - Tax strategy } \\
\text { - Supply chain } \\
\text { management } \\
\text { - Risk and crisis } \\
\text { management } \\
\text { - Corporate governance } \\
\text { - Materiality }\end{array}$ \\
\hline
\end{tabular}

The initial components of the proposed ESG framework are the common factors from the five reliable frameworks, and the common factors are housed under the generic categorization (pillars), E, S, and G. Section 4 details the proposed hierarchical ESG framework.

\section{Composition of Hierarchical Structure}

\subsection{Developing the Assessment Criteria}

The three-step task framework for AHP analysis in this study was determined as shown in Figure 2. The main criteria are E, S, and G, and these categories consist of five, six, and five sub-criteria, respectively.

The sub-criteria for this model selected common factors that overlap at least three out of five global information providers (Table 1). The sub-criteria under E are Resource Depletion, GHG Emissions, Pollution and Waste, Eco-Products/Process Strategies, and Natural Loss; the sub-criteria under S are Human Rights, Community Relations, Human Resource Management, Customer Satisfaction, and Social and Political Contributions; the sub-criteria under G are Ethical Behavior, Risks and Opportunity Management, Shareholder Rights, and Corporate Governance. In order to design an ESG model that reflects the 
specificities of South Korea, two Korea characterization factors, Partnership with Subcontractor under $\mathrm{S}$ and $\mathrm{CEO}$ Reputation under $\mathrm{G}$ are added to the proposed model. The reason for including these elements in the ESG model is that these two factors reflect the Chaebol (conglomerates) characteristics of South Korean economies. The market capitalization of Chaebol companies accounts for $60 \%$ of the KOSPI in 2019, and the annual revenue of the top 10 Chaebols exceeds the GDP of South Korea. Therefore, ESG adoption in financial markets should involve Chaebol-related social and governance problems that are specific to South Korea. These specificities are apparent when we refer to Google search trends of ESG, owner, and subcontracting. ESG searches across the world have been growing rapidly, but keyword searches on owners and subcontractors remain largely unchanged. However, in the case of South Korea, the frequency of ESG searches in recent years increased drastically, and the frequency of searches for owners and subcontractors shows a similar pattern of increase.

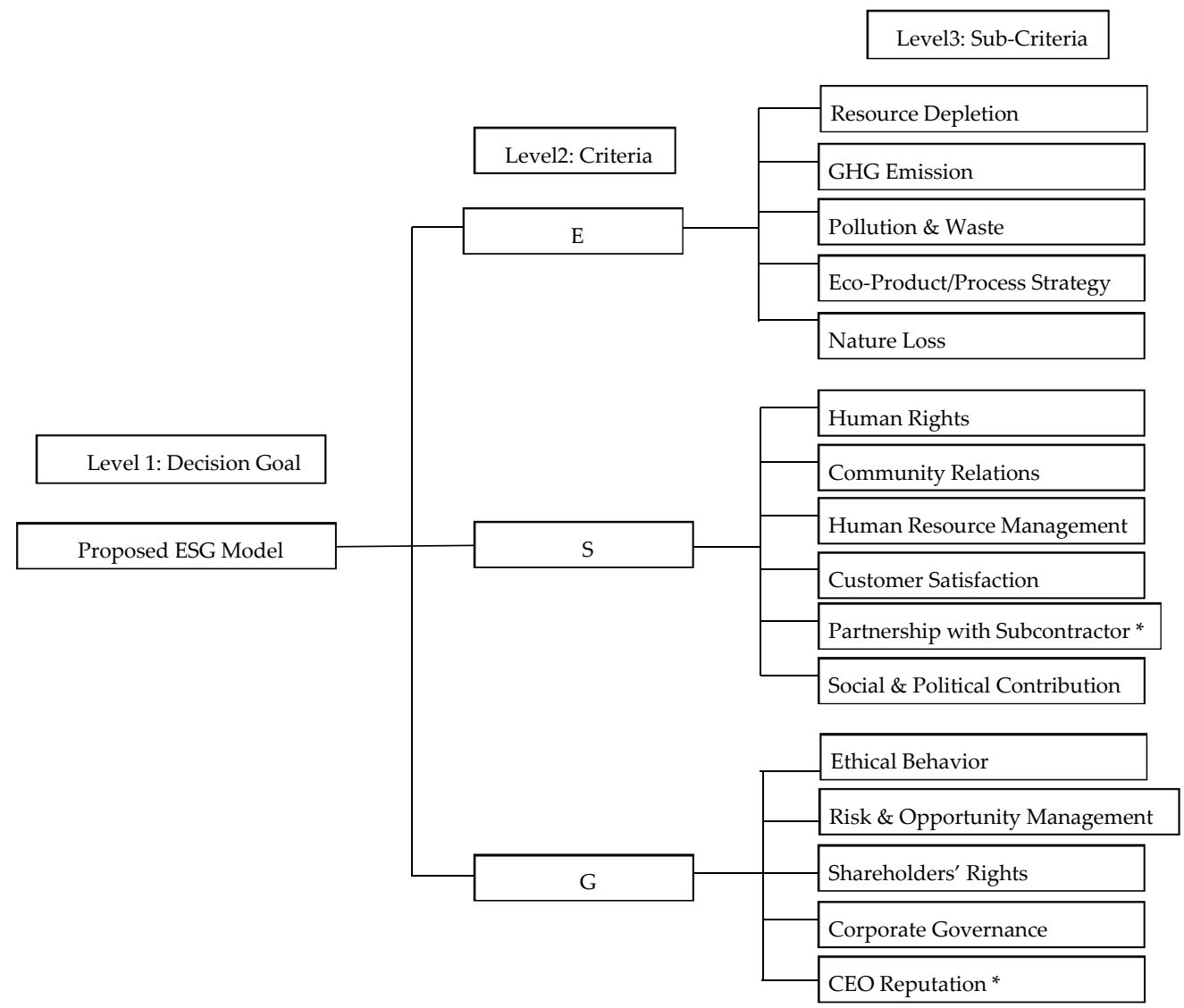

Figure 2. Hierarchical structure and composition of evaluation criteria (* signifies South Koreaspecific criteria).

Partnership with subcontractor under $\mathrm{S}$ is defined in our research as promoting satisfaction, trust, and inclusive growth with the partnership companies. Partners could include material sourcing companies, suppliers, and retailors, as well as contracted companies. In general, supply chain management in $S$ deals with upstream and downstream partner companies' ESG compliance. However, supply chain management does not wholly cover the Chaebol and subcontractor problem, which is posing serious social problems in South Korea. In the past, the growth of the Korean economy was driven by export-oriented policies and Chaebols, and the subcontractor problem was considered a social cost to endure. However, the trickle-down effect of the conglomerate system is gradually weakening, and the vertical subcontracting structure, which in the past had a positive effect on the growth of SMEs, is also deteriorating (Kim and Byun 2016). This is exacerbating the social problem of polarization of income and resource allocation. The market domination of large compa- 
nies leads to the monopolization of demand and unfair trade, and the burden of price cuts is passed on to subcontractors (Son 2012). It has also been revealed recently that some large companies are siphoning off technology from SMEs. In addition, Korean Chaebols are pursuing business diversification in almost all industries including construction, logistics, distribution, and software industries, which in turn reduces business opportunities for SMEs and hinders the dynamism of the entire economy. Therefore, it is important to create shared growth between large companies and subcontractors in order to find a paradigm for sustainable economic growth.

The other factor that reflects the specificities of Korea in this model is CEO reputation. The reputation of top management is critical to the success of the company. According to a report by Weber Weber Shandwick (2018), CEO reputation is one of the most valuable and competitive assets, and their survey results show that $45 \%$ of a company's reputation depends on it. Reputational risk refers to the possibility of an event occurring beyond our control that can negatively affect a company's reputation and pose a strategic threat to the business (Pineiro-Chousa et al. 2017).In the study of Francis et al. (2008) and Zerfass et al. (2014), the CEO's reputation has a great impact on the financial value of the company, and the CEO's reputation depends on strategic competence, credibility and communication ability, thus emphasizing the importance of strategic reputation management. Especially in South Korea, the reputation of the CEO greatly affects the value of the company. In many Korean companies, the founder himself runs the business without a professional manager and then hands over management rights to their second or third generation. In the ownership transition process, the owner-managers' management abilities and qualifications are not fully verified, and consequently, companies could suffer from damages caused by illegal acts, unfair and unexpected practices, and arbitrary management (Kim 2016).

Step 1 of AHP is identifying ESG factors to be included in the proposed countryspecific ESG model. We selected two Korea-specific factors along with 14 global criteria to present the overall model as shown in Figure 1, with a description of each sub-criteria and examples of measurement of those criteria in Table 2.

\subsection{Respondent Selection and Survey}

We selected institutional investors as the experts for AHP analysis, whose opinion will be extremely valuable in validating our ESG model factors. The role of institutional investors in South Korea has gradually increased in the past few years, becoming the predominant figure in financial markets (Woo and Kim 2015).

Institutional investors can be broadly classified into five groups: asset management companies, pension funds, insurance companies, securities companies, and bank. As of the end of 2020, institutional investors' holdings of Korean Won bonds reached 98\%. Among institutional investors, banks account for the largest share with $41 \%$, followed by insurance companies with $31 \%$, pension funds with $13 \%$, securities with $9 \%$, and asset management companies with 3\% (Ministry of Economy and Finance 2021). In the case of stocks, there are no sophisticated statistics on the holdings of each investor, as the holdings fluctuate frequently. As of the end of 2020, the proportion of stock holdings by individual investors has increased significantly, and it is estimated that they account for about $28 \%$ of the total stocks. It is also estimated that among institutional investors, asset management companies hold $30 \%$, pension funds hold $20 \%$, insurance companies hold $5 \%$, and securities companies and banks hold 5\%. 
Table 2. Description by criteria.

\begin{tabular}{|c|c|c|c|}
\hline Criteria & Sub-Criteria & Description & Measurement \\
\hline \multirow{5}{*}{$\mathrm{E}$} & Resource Depletion & $\begin{array}{l}\text { Managing the amount of energy and other } \\
\text { consumable resources }\end{array}$ & Energy/water consumption \\
\hline & $\begin{array}{l}\text { GHG (Greenhouse Gas) } \\
\text { Emission }\end{array}$ & $\begin{array}{c}\text { Managing and reducing the level of GHG } \\
\text { emissions to meet the target for the } \\
\text { Paris Agreement }\end{array}$ & $\begin{array}{l}\text { GHG emission and climate risk targets } \\
\text { and assessments, product } \\
\text { carbon footprint }\end{array}$ \\
\hline & Pollution and Waste & Managing the level of pollution and waste & $\begin{array}{c}\text { Waste disposal, water/air/land pollution, } \\
\text { single-use plastic }\end{array}$ \\
\hline & $\begin{array}{l}\text { Eco-Product/Process } \\
\text { Strategy }\end{array}$ & $\begin{array}{c}\text { Strategic efforts to reduce the corporate's } \\
\text { environmental impacts, i.e., produce more } \\
\text { using less resource }\end{array}$ & R\&D expenditure \\
\hline & Nature Loss & $\begin{array}{l}\text { Levels of potential damage to the nature and } \\
\text { efforts for ecological protection }\end{array}$ & $\begin{array}{l}\text { Land use and ecological } \\
\text { sensitivity, biodiversity }\end{array}$ \\
\hline \multirow{6}{*}{$S$} & Human Rights & $\begin{array}{l}\text { Respecting and securing human rights in the } \\
\text { business practices }\end{array}$ & $\begin{array}{l}\text { Discrimination, harassment, diversity } \\
\text { ratio, freedom of association, } \\
\text { child/forced/compulsory labor }\end{array}$ \\
\hline & Community Relations & $\begin{array}{l}\text { Efforts to build solid reputation and } \\
\text { relationship with local communities }\end{array}$ & Local investment, community investment \\
\hline & $\begin{array}{l}\text { Human Resources } \\
\text { Management }\end{array}$ & $\begin{array}{l}\text { Ensuring the dignity, equality, health, and } \\
\text { benefits of employees }\end{array}$ & $\begin{array}{c}\text { Talent attraction and retention } \\
\text { Providing health, safety and training } \\
\text { opportunities }\end{array}$ \\
\hline & Customer Satisfaction & $\begin{array}{c}\text { Provide products and services that satisfy } \\
\text { customers }\end{array}$ & $\begin{array}{l}\text { Privacy, data security, product safety and } \\
\text { quality, financial product safety }\end{array}$ \\
\hline & $\begin{array}{l}\text { Partnership with } \\
\text { Subcontractor }\end{array}$ & $\begin{array}{l}\text { Promoting satisfaction, trust, and inclusive } \\
\text { growth with subcontractor(s) }\end{array}$ & $\begin{array}{l}\text { Contract satisfaction, trusting } \\
\text { relationship }\end{array}$ \\
\hline & $\begin{array}{l}\text { Social and Political } \\
\text { Contribution }\end{array}$ & $\begin{array}{l}\text { As a responsible citizen, making effort to build } \\
\text { greater overall value to the society }\end{array}$ & $\begin{array}{l}\text { Contributions, philanthropy, } \\
\text { infrastructure investment, employment, } \\
\text { total tax paid }\end{array}$ \\
\hline \multirow{5}{*}{ G } & Ethical Behavior & $\begin{array}{l}\text { Monitoring and management to comply with } \\
\text { applicable laws and regulations }\end{array}$ & $\begin{array}{l}\text { Anti-competitive practices, } \\
\text { anti-corruption and bribery policy }\end{array}$ \\
\hline & $\begin{array}{l}\text { Risks and Opportunities } \\
\text { Management }\end{array}$ & $\begin{array}{c}\text { Identification and management of strategic } \\
\text { risks and opportunities regarding long-term } \\
\text { value creation }\end{array}$ & $\begin{array}{l}\text { Systemic risk management, critical } \\
\text { incident risk management, business } \\
\text { model resilience }\end{array}$ \\
\hline & Shareholders' Rights & $\begin{array}{l}\text { Upholding shareholders' concerns and voices } \\
\text { in company strategy and management }\end{array}$ & $\begin{array}{l}\text { Investment return, voting rights, } \\
\text { information disclosure }\end{array}$ \\
\hline & Corporate Governance & $\begin{array}{l}\text { Structure of management system that reflects } \\
\text { the direction and controlment of the company. } \\
\text { Impact of CEO and top management }\end{array}$ & $\begin{array}{l}\text { Gender ratio, experiences of the } \\
\text { board members }\end{array}$ \\
\hline & CEO Reputation & $\begin{array}{l}\text { personality and qualifications have on the } \\
\text { corporate image and value }\end{array}$ & CEO image, management controversy \\
\hline
\end{tabular}

The survey is designed to prioritize ESG categories and factors that investors make decisions on, and the survey participants were selected from those who met the following criteria while working in the top eight Korean financial institutions by asset size in each of the five industries:

- Period of service: at least 15 years of investment experience as an institutional investor

- Institutions at work: various types of financial institutions such as asset management companies, pension funds, insurers, securities firms, and banks

- Main business: Invest in various types of asset classes, including bond investment, equity investment, and alternative investment.

The survey was conducted from 11 June to 25 June 2021. The surveys questionnaires (please see Tables A1-A10 in the Appendix A and Figure 2) were distributed to the survey participants with detailed further explanations via phone and email. The survey is composed of 38 pairwise comparisons to find out the perceived importance of factors. A respondent was asked to choose one preferred pair and then the preference strength by using a scale ranging from the center, 1, (showing no preference) to 5 on the leftmost (showing 
the highest preference for $\mathrm{A}$ ) and 5 on the rightmost (showing the highest preference for B). Respondents were asked to fill out the questionnaire and reply by e-mail within the deadline. A total of 87 experts were contacted to respond to the survey; 79 responded to the survey. Analyzing the CR of 79 responses, it was confirmed that 25 of these responses exceeded the threshold level of $10 \%$ of the consistency ratio. Excluding these, 54 responses were finally selected as the subject of analysis in this paper.

The AHP method is a statistical method for analyzing and constructing complex decisions using ratio scale measurements (Felice et al. 2015). Many studies using the AHP method have been conducted by analyzing the opinions of a small group of advanced experts with a sample size of less than 20 to clarify hierarchical relationships for specific problems (Kil et al. 2016). This study was analyzed using 54 samples to reflect a wider range of expert opinions. The contents of the survey included questions about the investor's general perception of the company's ESG management as well as an assessment of the relative importance of each ESG criteria. The general perception of investors related to ESG management was checked through the following questions: (1) current level of interest in ESG management from an investor's perspective; (2) impact of a company's ESG management on the investors' investment; (3) perceived necessity of Korean ESG model; (4) adequacy of introduction and timing of ESG-related regulations and disclosures; (5) relevancy and consistency of ESG-related government policies. This is covered in detail in Section 5.4.

Samples in this survey are considered valid for the following reasons:

1. The 54 valid responses used in this study had a CR of less than $10 \%$ for individual respondents and less than $2 \%$ for group respondents. This is based on a guideline of using the AHP system provided by Goepel (2013).

2. As presented in Table 3, the experts in the sample are well distributed by institution and major businesses. The frequency of type by institution is less than $25 \%$.

3. The respondents in the sample are institutional investors and experts with an average of 20 years of experience in the investment field.

4. Most (74\%) of the respondents in the sample have past experience considering ESG factors as one of their investment decisions.

Table 3. Demographic information of valid survey respondents.

\begin{tabular}{ccccccccc}
\hline Type of Institution & Frequency & $\mathbf{\%}$ & Main Business & Frequency & $\mathbf{\%}$ & Service Period & Frequency & \% \\
\hline Asset Management & 11 & 20 & Bonds & 26 & 48 & $15-25$ years & 48 & 89 \\
Pension Fund & 13 & 24 & Stocks & 12 & 22 & Over 25 years & 6 \\
Insurance Company & 10 & 19 & Alternatives & 16 & 30 & & \\
Securities Company & 13 & 24 & & & & & \\
Bank & 7 & 13 & & & & & \\
\hline Total & 54 & 100 & Total & 54 & 100 & Total & 54 \\
\hline
\end{tabular}

The results from the analysis should demonstrate investors' view on factor importance, which is mainly concerned with their expected materiality of the factors (subcategories).

\section{Results}

\subsection{Weights of the Factors and Attributes}

After setting priority criteria hierarchically and gathering the survey results, the importance of criterion is determined based on the survey data. AHP uses linear algebra to evaluate the outcome of each pairwise comparison, and every criterion has its own weight. A higher weighted criterion means that it is more important in decision making (Ho and Ma 2018).

\subsubsection{Local Weights for Main Criteria (Level 2)}

As shown in Figure 3, the environmental factor (35.7\%) and governance factor (34.8\%) were found to be almost equally important in the analysis of the factors that influence 
corporate ESG management on institutional investors' investment decisions, while social factors $(29.5 \%)$ were found to have relatively little importance.

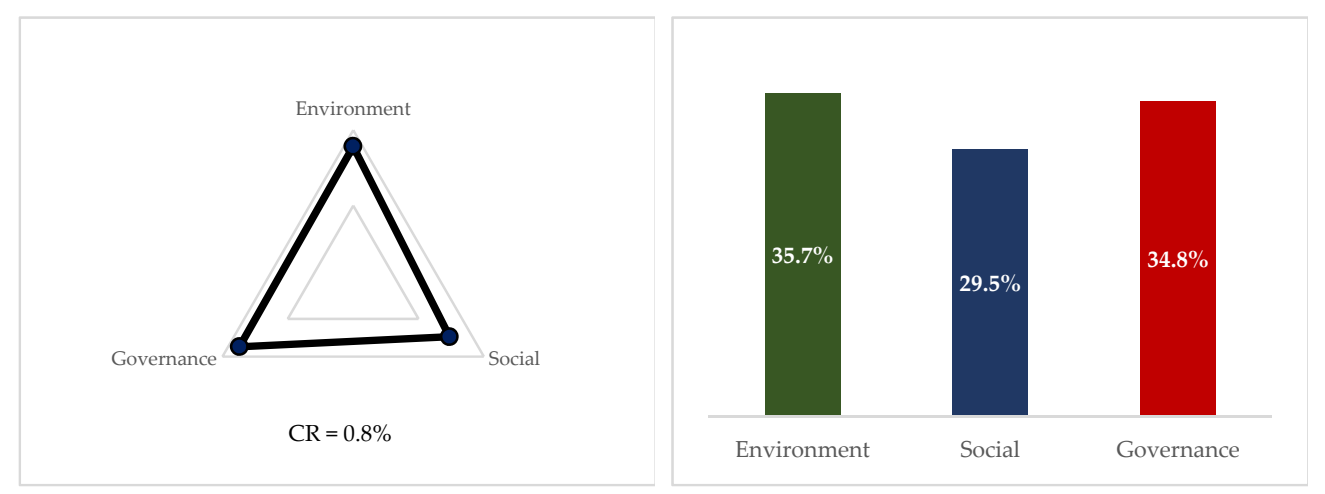

Figure 3. Local weights for level 2 (ESG).

\subsubsection{Local Weights for Sub-Criteria}

\section{Local Weights for Environmental Factors}

The environmental factor includes resource depletion, GHG emission, pollution and waste, eco-product/process strategy, and nature loss. As shown in Figure 4, it was found that institutional investors' investment decisions are affected by the following variables in the order of importance: pollution and waste (25.9), GHG emission (25.3\%), eco-product/process strategy (20.2\%), nature loss (16.2\%), and resource depletion (12.4\%).
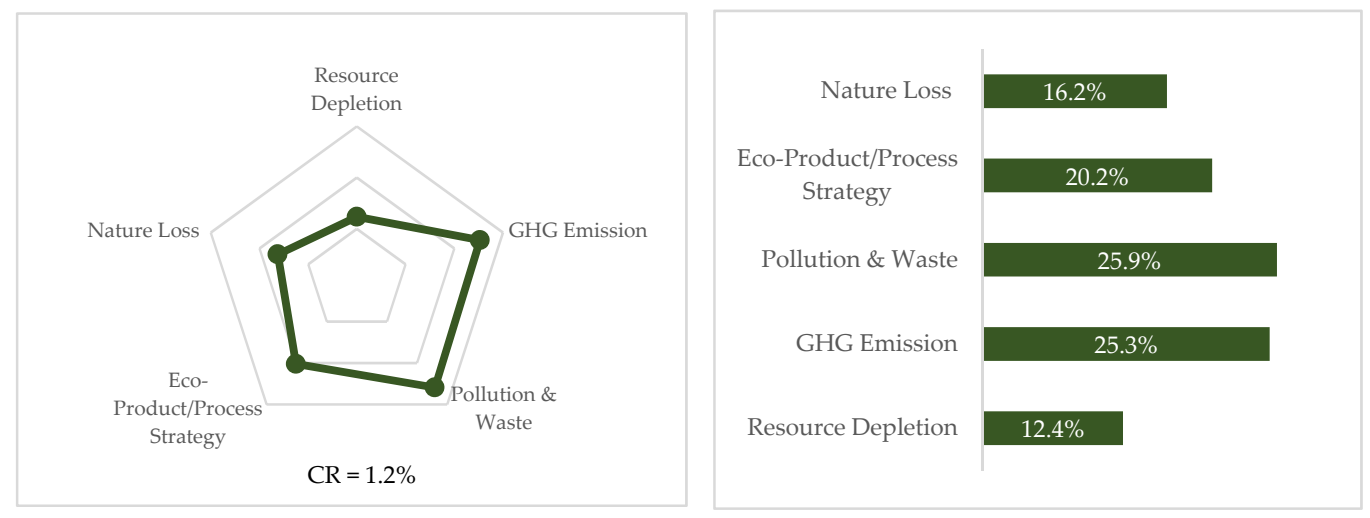

Figure 4. Local weights for E, environmental factors.

\section{Local Weights for Social Factors}

Elements considered as social factors are human rights, community relations, human resources management, customer satisfaction, partnership with subcontractor, and social and political contribution. As presented in Figure 5, customer satisfaction (27.1\%) has the most impact on institutional investors' decisions in relation to ESG management, which was followed by the partnership with subcontractor $(23.1 \%)$, community relations $(17.4 \%)$, human resource management $(13.9 \%)$, human rights $(13.1 \%)$, and social and political contribution $(5.1 \%)$. 

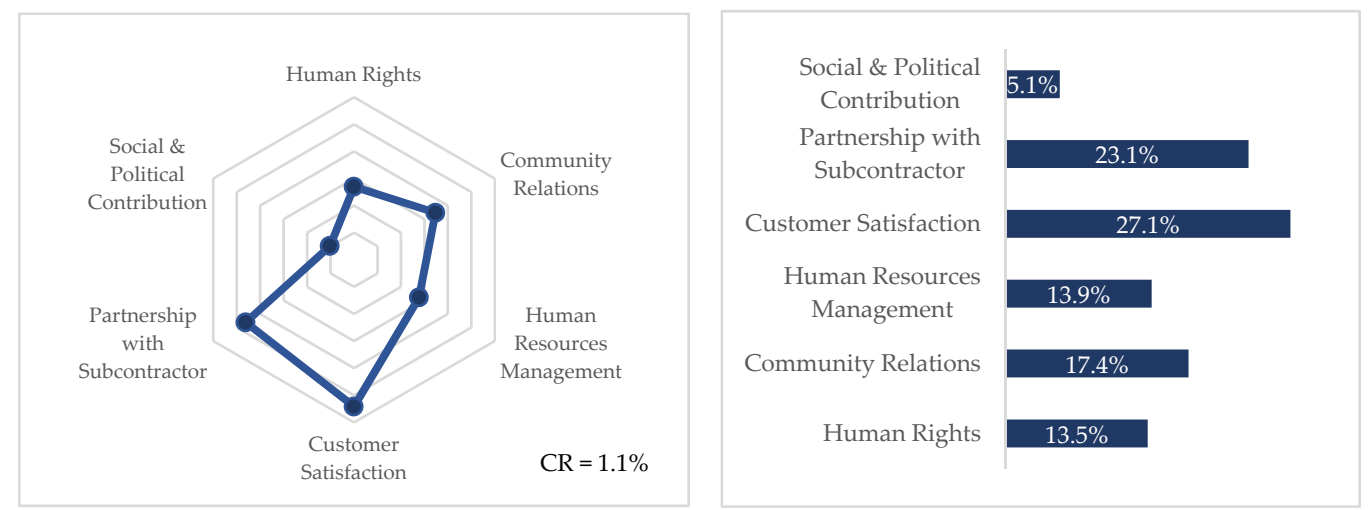

Figure 5. Local weights for S, social factors.

\section{Local Weights for Governance Factors}

Governance factor is classified as ethical behavior, risks and opportunities management, shareholders' rights, corporate governance, and CEO reputation. The order of importance was investigated as shown in Figure 6: shareholders' rights (27.2\%), risks and opportunities management $(23.1 \%)$, CEO reputation (20.4\%), corporate governance $(20.9 \%)$, and ethical behavior (8.4\%).
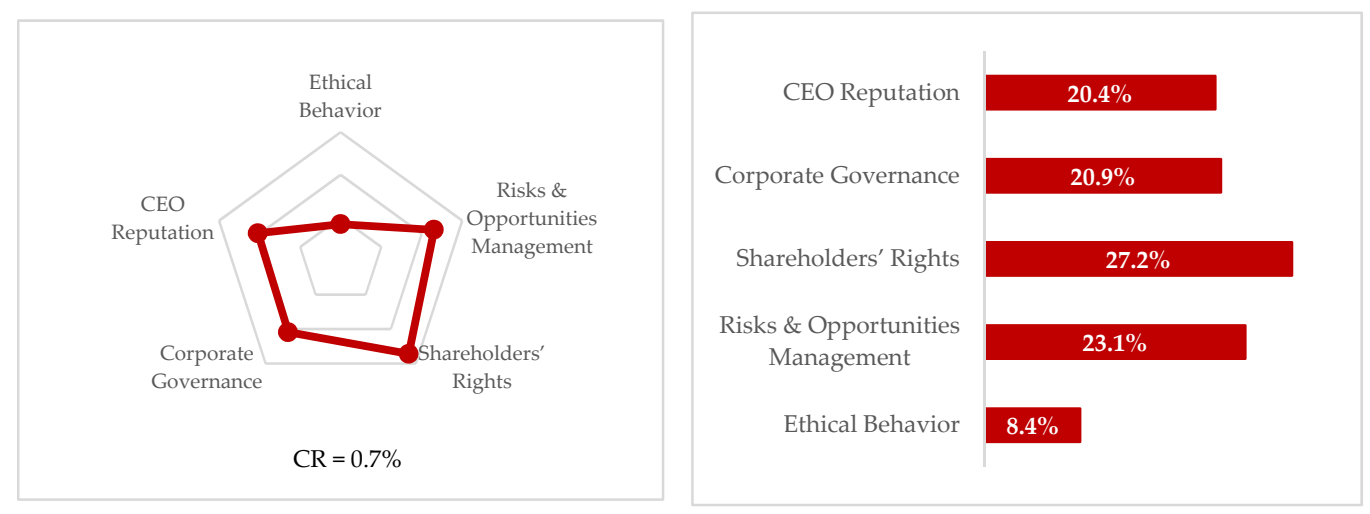

Figure 6. Local weights for $G$, governance factors.

\subsubsection{Global Weights for Sub-Criteria}

The global weights of ESG elements are shown in Figure 7. The global weight is a multiplication of the importance derived from each criterion. The sum of all the lowest sub-criteria under the three main criteria comes up to be $100 \%$. Local weights represent the relative rank of pairwise comparisons at each level; global weights determine the aggregate importance of the smallest unit coefficients in the AHP hierarchy.

Among the 16 sub-criteria of ESG, shareholders' rights, pollution and waste, GHG emission, and risk and opportunities management were found to have the most important influences on institutional investors' investment decisions. However, social and political contribution, ethical behavior, and human rights were analyzed to have relatively little influence. The CEO reputation and partnership with subcontractor qualities, which reflect South Korea's specificities, are in the middle of the overall rankings, suggesting that they are major considerations in South Korean institutional investors' investment decisions. 


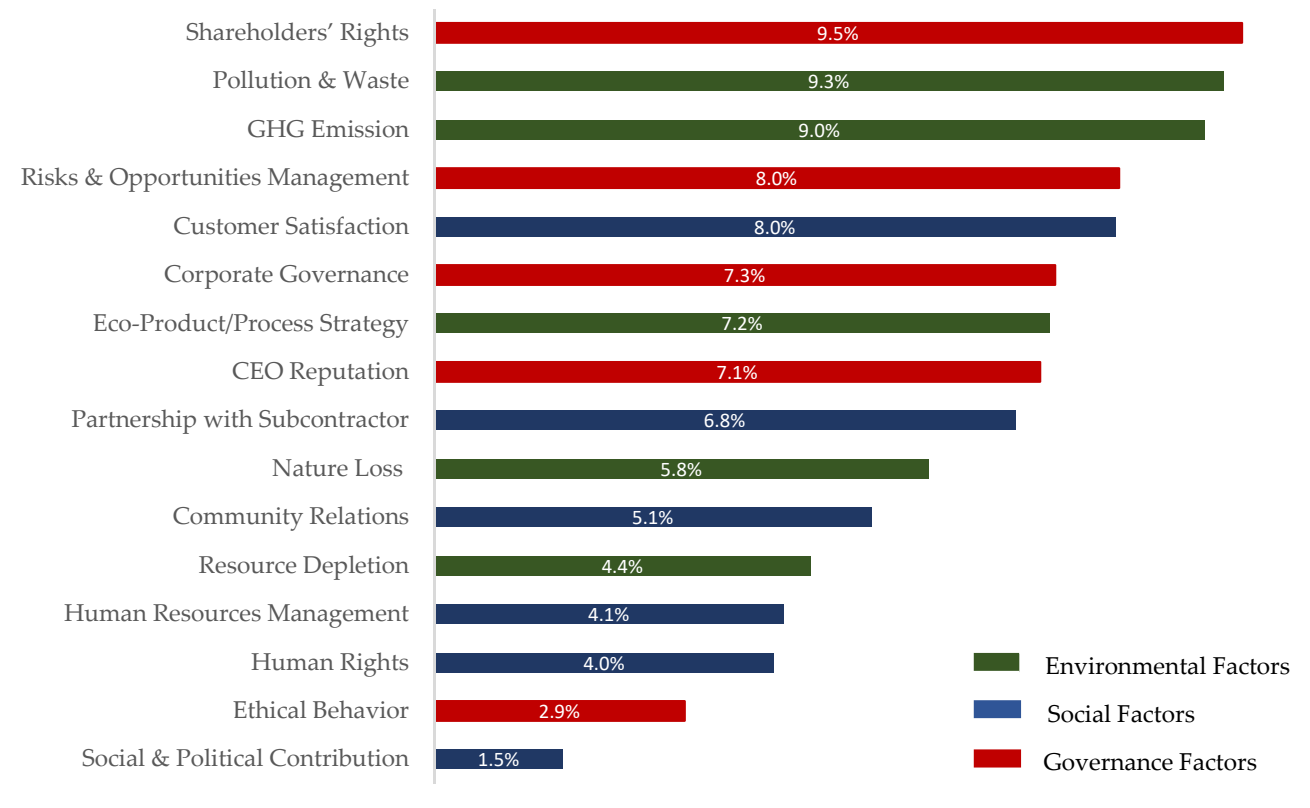

Figure 7. Global weights.

5.2. Weights of the Factors and Attributes Divided by Five Groups (by Investment Institution) and by Three Groups (by Main Business)

To derive more detailed implications, this study divides the survey respondents into five institution types and three main business types, respectively, and compares their weights. The first group divided the entire sample by investment institution into securities firms, banks, asset management companies, insurance companies, and pension funds, and the second group analyzed them by major businesses of bond investment, stock investment, and alternative investment. The purpose of this comparative analysis is to provide a more concrete idea of the ESG area that companies and policy authorities should focus on managing.

\subsubsection{Global Weights of the Factors and Attributes Divided by Five Groups (by} Investment Institution)

For stable financing, it is important for companies to understand the perceptions of institutional investors, especially those with long-term investment propensity (Jang and Atukeren 2019). As Figure 8 shows, pension funds and insurers with long-term investment propensity have been shown to place high importance on shareholders' rights, risk and opportunity management, and CEO reputation. Investors belonging to asset managers and securities firms with short-term investment tendencies placed higher scores on customer satisfaction, eco-friendly products, and process strategies. Investors working in banks, on the other hand, expressed mixed opinion.

5.2.2. Global Weights of the Factors and Attributes Divided by Three Groups (by Main Business)

As shown in Figure 9, no significant differences were found between the major businesses. Looking at the characteristic differences, investors whose main business is stock investment are more sensitive to shareholders' rights and customer satisfaction. Meanwhile, investors who focus on bond investments gave higher marks on risk and opportunity management. On the other hand, investors with alternative investments as their primary business were analyzed to place more importance on environmental factors such as GHG emissions, pollution and waste, and green products and process strategies. 


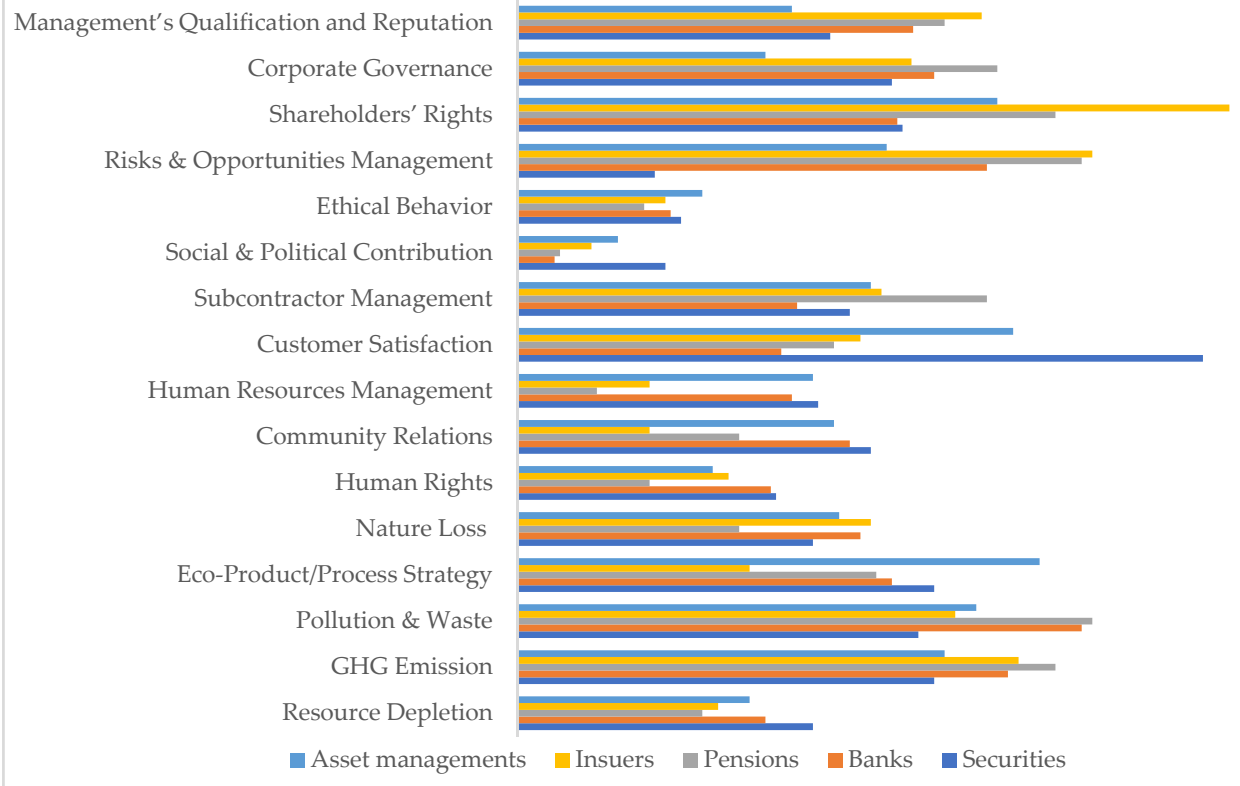

Figure 8. Global weights by investment institution.

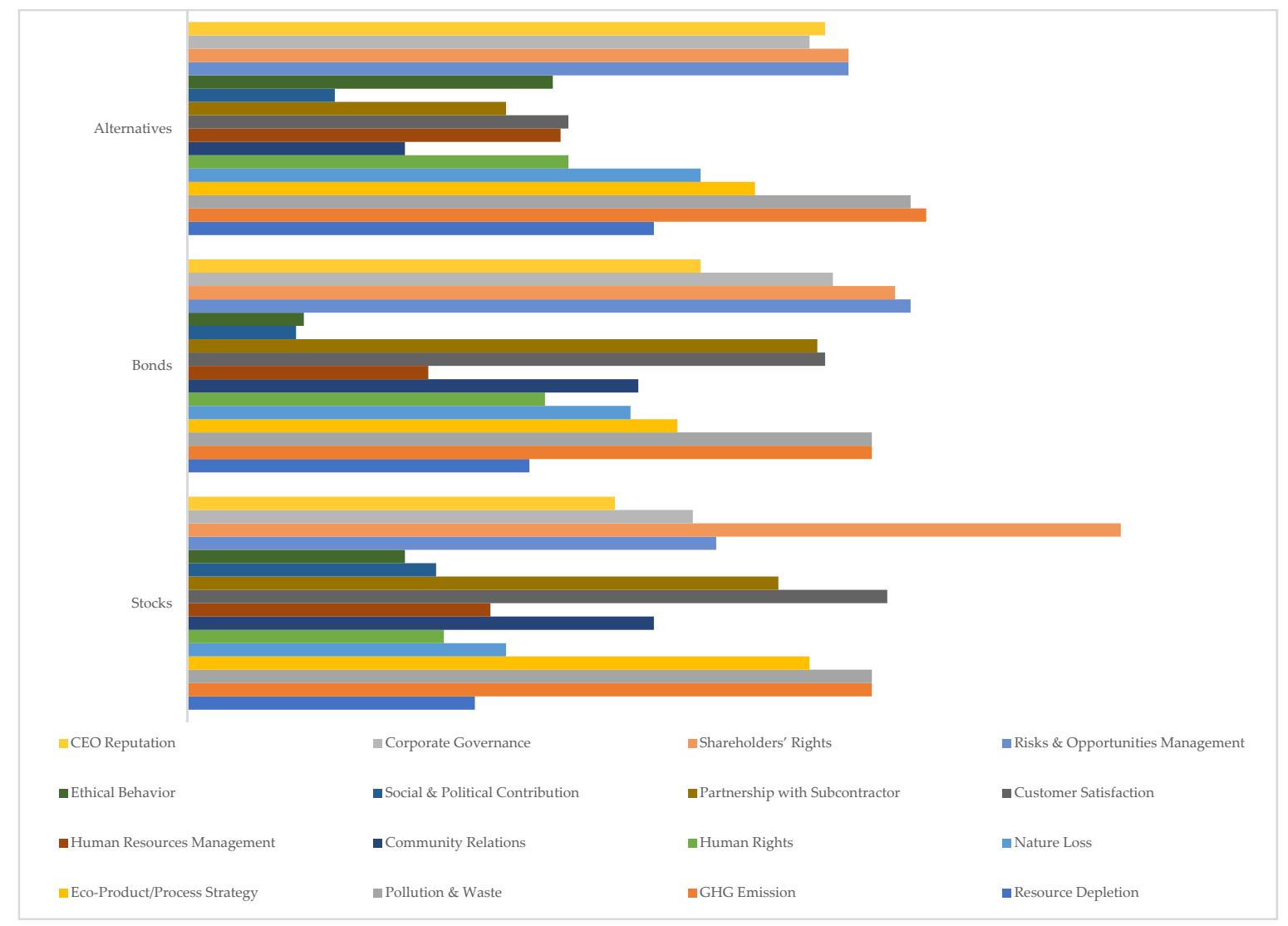

Figure 9. Global weights by main business.

\subsection{Consensus Level}

Consensus must be strictly distinguished from consistency ratio. Goepel (2013) suggested the AHP group consensus factor, which is an estimate of consensus on priorities among participants. These factors range from $0 \%$ to $100 \%$. Zero percent consensus corresponds to no agreement at all, and 100\% consensus corresponds to complete agreement. 
This is a measure of priority homogeneity among participants and can also be interpreted as a measure of redundancy among group members (Jost 2006). Values below 50\% indicate that there is virtually no agreement within the group and that judgment is highly variable. Values ranging from $80 \%$ to $90 \%$ indicate overlapping priorities and superior judgment consensus among group members.

As shown in Figure 10, the overall consensus of ESG was 81\%. With the exception of securities companies $(68 \%)$, the consensus for each institution is over $80 \%$. In particular, it was found that pension funds $(89 \%)$ and insurance companies $(86 \%)$ had high consensus levels. For each element of ESG, it was analyzed that there was $83 \%$ consensus for E, $74 \%$ for $\mathrm{S}$, and $86 \%$ for $\mathrm{G}$.

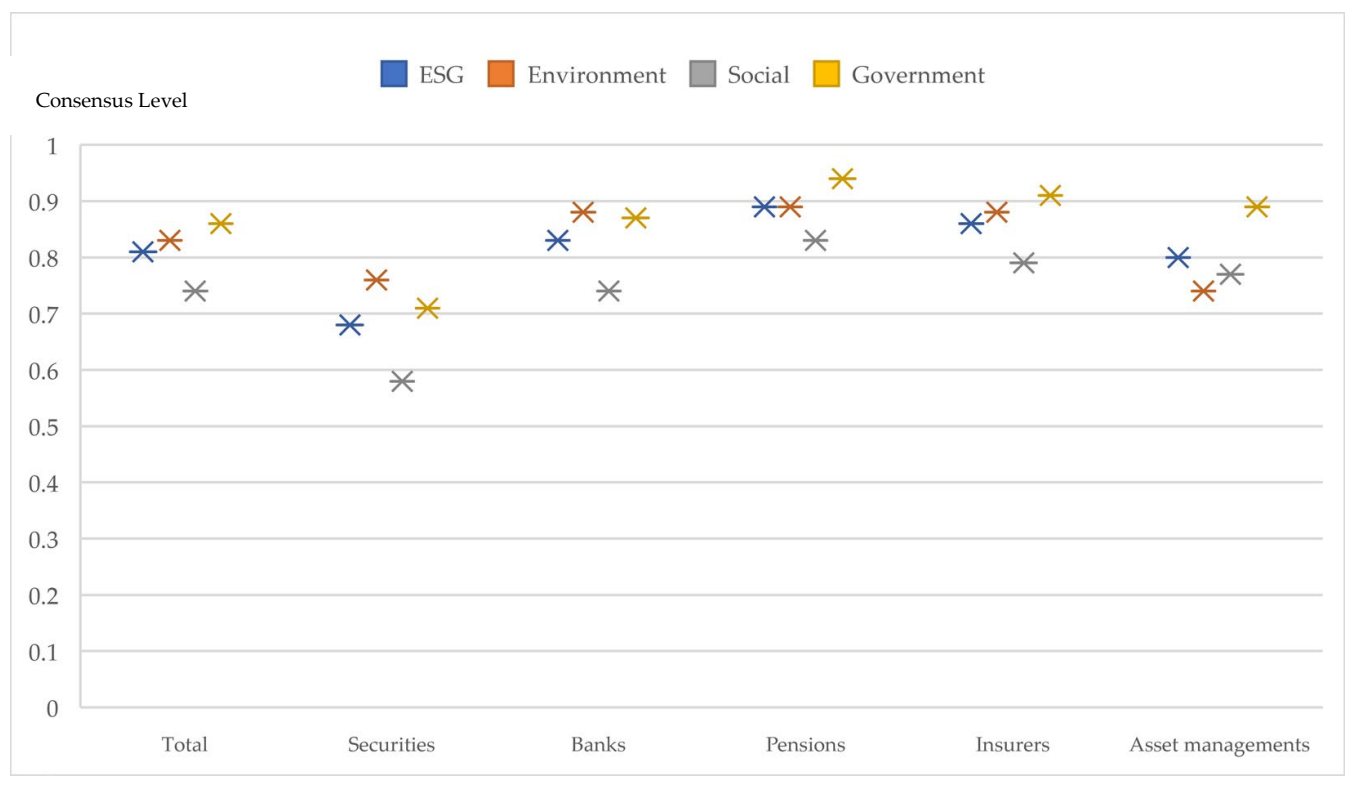

Figure 10. Consensus measure.

\subsection{Other Discussion Points}

In addition to the pairwise comparison, the survey also examined investors' overall perception of ESG management. Of the 54 valid respondents, 47 (87\%) said that companies' ESG performance is currently affecting their investment decisions, and $50(93 \%)$ expect ESG factors to have a greater impact on investment decisions in the future. Meanwhile, $41(76 \%)$ said that a Korean-style ESG model is very necessary, and more than $60 \%$ said that the timing of requiring disclosure of companies' ESG-related information and bringing out enforceable ESG regulations is appropriate. However, there were responses questioning the consistency of government policy in relation to corporate management.

\section{Conclusions}

This study presents a new Korean ESG model and identifies institutional investors' perceptions of ESG factors.

New investors may be reluctant to invest in companies that lack satisfactory ESG performances, and existing investors could exercise the stewardship code at shareholders' meetings when the company is not up to par with ESG practices. The past few years in South Korea mark the transition period into the age of sustainable management practices backed by ESG adoption. Korea's National Pension Service, one of the world's top three pension funds, plans to come up with detailed investment guidelines for ESG and drastically increase the proportion of ESG-related investments from 4\% in 2019 to $50 \%$ in 2022 (National Pension Service 2021). Some Korean conglomerates are also responding to this movement. For example, Samsung Group's financial affiliates announced that it will stop investing in coal power plants, and Samsung Electronics has decided to use eco-friendly 
materials for its video display products. Hyundai Motor Group replaced outside directors with ESG experts, and affiliated steelmakers have started building a database related to carbon emissions. SK Group's six affiliates were the first Korean companies to receive RE100 approval. According to the Beyond Coal (2018) survey, 89\% of South Korea's major asset managers said that they would no longer invest in coal-based companies, confirming that there has been a shift in consensus amongst asset managers.

Although these recent changes are taking place in South Korea, there has been no agreement on the ESG evaluation model so far. Corporations are confused by ESG evaluation standards and regulations on which to base their ESG management, and investors also disagree on the reference index on which to base their investment decisions. This confusion on ESG standards can deter both corporates and investors from making the necessary changes for sustainability.

We present a commonly applicable model to remedy the confusion that investors and corporates are currently facing in South Korea. This model is designed by identifying common factors of five global leading information providers and adding two country-specific factors to reflect the specificities of South Korea. The model considers environmental, social, and governance factors as its main criteria. Sub-criteria under environmental factors include resource depletion, GHG emission, pollution and waste, eco-product/process strategy, and nature loss. Under social factors, it considers human rights, community relations, human resources management, customer satisfaction, partnership with subcontractors, and social and political contribution. Finally, sub-criteria under governance factors consist of ethical behavior, risks and opportunities management, shareholders' rights, corporate governance, and CEO reputation. To analyze the relative importance of each criterion, an expert survey was conducted using the AHP analytical technique.

As a result of the analysis, it was found that institutional investors perceive that the environment and corporate governance are more important than social factors in their investment decisions. The results of our study show slightly different results compared to the weights given by Refinitiv (2021), where environmental factors were given the most weight followed by social and governance factors. In addition, MSCI's industryspecific weights were the highest for social factors, and weightings for environmental and governance factors were similar (Nagy et al. 2020). In addition, the global weight analysis of the sub-criteria found that shareholder rights, pollution and waste, greenhouse gas emissions, and risk and opportunity management had relatively greater influences on investment decisions. Further analysis by investment institutions showed that investors with strong long-term investment propensities, such as pension funds and insurance companies, paid more attention to shareholders' rights, risk and opportunity management, and CEO reputation. On the other hand, investors with higher propensities for short-term investment, such as securities and asset management companies, were found to place more importance on customer satisfaction and eco-friendly products and process strategies. With regard to the South Korean-specified variables used in this model, CEO reputation ranked eighth and partnerships with subcontractors ranked ninth out of a total of 16 variables, confirming that these are important factors to include in the country-specific ESG model for South Korea.

Our research focused on country-specific factors as well as common global factors, and it gathered investors' opinions on these factors. Country-specific factors can provide more stable performance predictions of companies that have adopted ESG (Sherwood and Pollard 2017) and help companies focus more on relevant ESG issues. Having common global factors in the proposed ESG model allows for the standardization of evaluation factors, which enables comparisons of data across the globe. With the proposed model, we expect the following implications for corporate management and stakeholders. First, having an established framework gives companies a concrete direction for management on what sustainability issues to focus on. In addition, utilizing the framework will help companies comply with laws and regulations proactively. Secondly, our country-specific model will make adopting ESG disclosures and practices easier for companies. Companies 
with good ESG disclosure practices will be more attractive in the stock and bond markets as well as to their customers. Lastly, participants within the supply chain and customers can benefit from an ESG framework specifically made for the country's specificities. Companies can focus more on impending issues within nations, and the resolution of the issues will benefit the concerned stakeholders. In addition, our framework adopts global standards, and issues related to stakeholders will certainly reflect global standards. For example, human rights, employee training, R\&D, material sourcing, supply chain management, and other issues can be dealt with by the global perspectives presented with our model.

There are limitations in the current research. The survey was conducted to find out South Korean institutional investors' perceptions only. In addition, the study does not test generalizability across industries. In future research, it may be interesting to broaden the scope of the study to other emerging and advanced economies. In addition, ESG adoption steps and ESG model criteria should vary from industry to industry due to the costs associated with ESG management and the nature of production and sales processes. Therefore, it would be worthwhile to study the ESG criteria based on industrial differences.

Author Contributions: Conceptualization, J.Y.J.; Data curation, S.R.P.; Formal analysis, S.R.P.; Investigation, S.R.P.; Methodology, J.Y.J.; Supervision, J.Y.J.; Writing—original draft, S.R.P.; Writing—review and editing, J.Y.J. All authors have read and agreed to the published version of the manuscript.

Funding: This research received no external funding.

Institutional Review Board Statement: Not applicable.

Informed Consent Statement: Not applicable.

Data Availability Statement: Not applicable.

Acknowledgments: We sincerely thank Erdal Atukeren at Business School Lausanne, Brian Jang at Marcus \& Associates, anonymous referees and the editors for their constructive and valuable comments and suggestions, which have helped us tremendously improve on the manuscript.

Conflicts of Interest: The authors declare no conflict of interest.

\section{Appendix A}

Survey Qestionarie

The purpose of this survey is to conduct a survey to understand institutional investor awareness in relation to ESG management (E: Environment, S: Social, G: Governance), which has recently become a hot topic around the world, including South Korea.

We acknowledge that the contents of your responses to the survey are the opinions of the individual respondent, not the opinions of the organization to which you belong. In addition, it is clearly stated that your comments will be used only for academic research purposes and will not be used for any other commercial purposes.

$<$ Survey Directions >

1. Please answer the entire questions.

2. Answers must be logically consistent. For example, if $A$ is more important than $B$ and $B$ is more important than $C$, then $A$ is more important than $C(A>B$ and $B>C-A>C)$.

If you have any inquiry about the survey, please do not hesitate to contact us (Person in charge: Jae Young Jang and So Ra Park). 
Table A1. Basic data for survey respondents.

\begin{tabular}{|c|c|}
\hline \multirow{2}{*}{1} & What field are you currently working in? \\
\hline & (1) Asset management (2) Pension fund (3) Insurance (4) Securities (5) Bank (6) Other ( ) \\
\hline \multirow{2}{*}{2} & In which area of your investment business are you currently working? \\
\hline & (1) Stocks (2) Bonds (3) Alternative investment (4) Management (5) Others ( ) \\
\hline \multirow{2}{*}{3} & How many years have you worked in the entire investment field? \\
\hline & (1) 15 years or less (2) $15-25$ years (3) 25 years or more \\
\hline \multirow{2}{*}{4} & To what extent do you have an understanding and interest in ESG? \\
\hline & (1) Very large (2) Large (3) Average (4) Small (5) Not at all \\
\hline \multirow{2}{*}{5} & Have you ever considered ESG as an investment decision factor when making an investment decision? \\
\hline & (1) Yes (2) No \\
\hline \multirow{2}{*}{6} & To what extent do you see the impact of ESG on the future investment environment? \\
\hline & (1) Expected to be very large (2) Moderate (3) Not expected to be significant \\
\hline \multirow[t]{2}{*}{7} & $\begin{array}{l}\text { Countries around the world are preparing laws and regulations to have companies' disclosure } \\
\text { regarding ESG practices. In this regard, do you think it is necessary to have a separate Korean ESG } \\
\text { (K-ESG) framework reflecting Korean business/economic and social characteristics? }\end{array}$ \\
\hline & (1) Very necessary (2) Necessary (3) Not necessary \\
\hline \multirow[t]{2}{*}{8} & $\begin{array}{l}\text { The South Korean government is planning to introduce various regulations and ESG disclosure } \\
\text { systems, such as making ESG-related disclosures mandatory for all KOSPI-listed companies from } 2030 . \\
\text { How do you feel about the timeline of the current Korean ESG (K-ESG) introduction? }\end{array}$ \\
\hline & (1) Appropriate (2) Moderate (3) Too fast \\
\hline \multirow{2}{*}{9} & Do you evaluate the consistency of the government's policies related to business management? \\
\hline & (1) Consistent (2) Moderate (3) Very inconsistent \\
\hline
\end{tabular}

Table A2. Evaluation scale.

\begin{tabular}{ccc}
\hline Measurement Item & Evaluation Scale & Measurement Item \\
\hline \multirow{2}{*}{ A } & 543212345 & \multirow{2}{*}{ B } \\
\cline { 2 - 3 } & Extremely Important Equal Extremely Important & \\
\hline
\end{tabular}

Table A3. Main criteria: definitions and descriptions of key components.

\begin{tabular}{|c|c|c|}
\hline Criteria & Description & Measurement \\
\hline $\begin{array}{l}\text { Environmental } \\
\text { Factors }\end{array}$ & $\begin{array}{l}\text { Measure the company's } \\
\text { environmental reporting and } \\
\text { environmental risks, and pursue } \\
\text { innovation opportunities for } \\
\text { sustainable growth }\end{array}$ & $\begin{array}{c}\text { Composition of subcategories: resource } \\
\text { consumption, greenhouse gas emission, } \\
\text { pollution and waste emission, } \\
\text { eco-friendly products and production } \\
\text { process strategy, nature loss }\end{array}$ \\
\hline Social Factors & $\begin{array}{l}\text { Understand the impact of } \\
\text { corporate activities on } \\
\text { stakeholders, and pursue social } \\
\text { values as a member of the } \\
\text { local community }\end{array}$ & $\begin{array}{l}\text { Subcategory composition: human } \\
\text { rights protection, community relations, } \\
\text { human resource management, } \\
\text { customer satisfaction, partnership with } \\
\text { subcontractor, social and } \\
\text { political contribution }\end{array}$ \\
\hline $\begin{array}{l}\text { Environmental } \\
\text { Factors }\end{array}$ & $\begin{array}{l}\text { Corporate management aligns the } \\
\text { interests of shareholders, } \\
\text { management, and workers, and } \\
\text { pursues sustainable } \\
\text { growth strategies }\end{array}$ & $\begin{array}{l}\text { Subcategory composition: ethical } \\
\text { behavior, risks and opportunities } \\
\text { management, shareholders' rights, } \\
\text { corporate governance, CEO reputation }\end{array}$ \\
\hline
\end{tabular}


Table A4. Main criteria question items.

\begin{tabular}{ccc}
\hline Measurement Item & Evaluation Scale & Measurement Item \\
\hline Environmental Factors & 543212345 & Social Factors \\
\hline Social Factors & 543212345 & Governance Factors \\
\hline Environmental Factors & 543212345 & Governance Factors \\
\hline
\end{tabular}

1. Environmental Factors

Table A5. Sub-criteria (environmental factors): definitions and descriptions of key components.

\begin{tabular}{|c|c|c|c|}
\hline Criteria & Sub-Criteria & Descriptions & Measurements \\
\hline \multirow{5}{*}{$\mathrm{E}$} & $\begin{array}{l}\text { Resource } \\
\text { Depletion }\end{array}$ & $\begin{array}{l}\text { Managing the amount of } \\
\text { energy and other consumable } \\
\text { resources }\end{array}$ & $\begin{array}{l}\text { Energy/water } \\
\text { consumption }\end{array}$ \\
\hline & $\begin{array}{l}\text { GHG } \\
\text { (Greenhouse Gas) } \\
\text { Emission }\end{array}$ & $\begin{array}{c}\text { Managing and reducing the } \\
\text { level of GHG emissions to } \\
\text { meet the target for the Paris } \\
\text { Agreement }\end{array}$ & $\begin{array}{l}\text { GHG emission and climate } \\
\text { risk targets and } \\
\text { assessments, product } \\
\text { carbon footprint }\end{array}$ \\
\hline & $\begin{array}{l}\text { Pollution and } \\
\text { Waste }\end{array}$ & $\begin{array}{l}\text { Managing the level of } \\
\text { pollution and waste }\end{array}$ & $\begin{array}{l}\text { Waste disposal, } \\
\text { water/air/land pollution, } \\
\text { single use plastic }\end{array}$ \\
\hline & $\begin{array}{c}\text { Eco- } \\
\text { Product/Process } \\
\text { Strategy }\end{array}$ & $\begin{array}{l}\text { Strategic efforts to reduce the } \\
\text { corporate's environmental } \\
\text { impacts, i.e., produce more } \\
\text { using less resource }\end{array}$ & R\&D expenditure \\
\hline & Nature Loss & $\begin{array}{l}\text { Levels of potential damage to } \\
\text { the nature and efforts for } \\
\text { ecological protection }\end{array}$ & $\begin{array}{l}\text { Land use and ecological } \\
\text { sensitivity, biodiversity }\end{array}$ \\
\hline
\end{tabular}

Table A6. Environmental factor question items.

\begin{tabular}{ccc}
\hline Measurement Item & Evaluation Scale & Measurement Item \\
\hline Resource Depletion & 543212345 & GHG (Greenhouse Gas) Emission \\
\hline Resource Depletion & 543212345 & Pollution and Waste \\
\hline Resource Depletion & 543212345 & Eco-Product/Process Strategy \\
\hline Resource Depletion & 543212345 & Nature Loss \\
\hline GHG (Greenhouse Gas) Emission & 543212345 & Pollution and Waste \\
\hline GHG (Greenhouse Gas) Emission & 543212345 & Eco-Product/Process Strategy \\
\hline GHG (Greenhouse Gas) Emission & 543212345 & Nature Loss \\
\hline Pollution and Waste & 543212345 & Eco-Product/Process Strategy \\
\hline Pollution and Waste & 543212345 & Nature Loss \\
\hline Eco-Product/Process Strategy & 543212345 & Nature Loss
\end{tabular}




\section{Social Factors}

Table A7. Sub-criteria (social factors): definitions and descriptions of key components.

\begin{tabular}{|c|c|c|c|}
\hline Criteria & Sub-Criteria & Description & Measurement \\
\hline \multirow{6}{*}{$S$} & Human Rights & $\begin{array}{l}\text { Respecting and securing } \\
\text { human rights in the business } \\
\text { practices }\end{array}$ & $\begin{array}{c}\text { Discrimination, } \\
\text { harassment, diversity ratio, } \\
\text { freedom of association, } \\
\text { child/forced/compulsory } \\
\text { labor }\end{array}$ \\
\hline & Community Relations & $\begin{array}{l}\text { Efforts to build solid } \\
\text { reputation and relationship } \\
\text { with local communities }\end{array}$ & $\begin{array}{l}\text { Local investment, } \\
\text { community investment }\end{array}$ \\
\hline & $\begin{array}{l}\text { Human Resources } \\
\text { Management }\end{array}$ & $\begin{array}{l}\text { Ensuring the dignity, } \\
\text { equality, health, and benefits } \\
\text { of employees }\end{array}$ & $\begin{array}{l}\text { Talent attraction } \\
\text { and retention } \\
\text { Providing health, safety }\end{array}$ \\
\hline & Customer Satisfaction & $\begin{array}{l}\text { Provide products and } \\
\text { services that satisfy } \\
\text { customers }\end{array}$ & $\begin{array}{l}\text { Privacy, data security, } \\
\text { product safety and quality, } \\
\text { financial product safety }\end{array}$ \\
\hline & $\begin{array}{l}\text { Partnership with } \\
\text { Subcontractor }\end{array}$ & $\begin{array}{l}\text { Promoting satisfaction, trust, } \\
\text { and inclusive growth with } \\
\text { subcontractor(s) }\end{array}$ & $\begin{array}{l}\text { Contract satisfaction, } \\
\text { trusting relationship }\end{array}$ \\
\hline & $\begin{array}{l}\text { Social and Political } \\
\text { Contribution }\end{array}$ & $\begin{array}{l}\text { As a responsible citizen, } \\
\text { making effort to build greater } \\
\text { overall value to the society }\end{array}$ & $\begin{array}{c}\text { Contributions, } \\
\text { philanthropy, } \\
\text { infrastructure investment, } \\
\text { employment, total tax paid }\end{array}$ \\
\hline
\end{tabular}

Table A8. Social factor question items.

\begin{tabular}{ccc}
\hline Measurement Item & Evaluation Scale & Measurement Item \\
\hline Human Rights & 543212345 & Community Relations \\
\hline Human Rights & 543212345 & Customer Satisfaction \\
\hline Human Rights & 543212345 & Human Resources Management \\
\hline Human Rights & 543212345 & Partnership with Subcontractor \\
\hline Human Rights & 543212345 & Social and Political Contribution \\
\hline Community Relations & 543212345 & Customer Satisfaction \\
\hline Community Relations & 543212345 & Human Resources Management \\
\hline Community Relations & 543212345 & Partnership with Subcontractor \\
\hline Community Relations & 543212345 & Social and Political Contribution \\
\hline Customer Satisfaction & 543212345 & Human Resources Management \\
\hline Customer Satisfaction & 543212345 & Partnership with Subcontractor \\
\hline Customer Satisfaction & 543212345 & Social and Political Contribution \\
\hline Human Resources Management & 543212345 & Partnership with Subcontractor \\
\hline Human Resources Management & 543212345 & Social and Political Contribution \\
\hline Partnership with Subcontractor & 543212345 & Social and Political Contribution \\
\hline
\end{tabular}




\section{Governance Factors}

Table A9. Sub-criteria (governnance factors): definitions and descriptions of key components.

\begin{tabular}{|c|c|c|c|}
\hline Criteria & Sub-Criteria & Description & Measurement \\
\hline \multirow{6}{*}{ G } & Ethical Behavior & $\begin{array}{l}\text { Monitoring and management to } \\
\text { comply with applicable laws and } \\
\text { regulations }\end{array}$ & $\begin{array}{l}\text { Anti-competitive } \\
\text { practices, anti-corruption } \\
\text { and bribery policy } \\
\text { Systemic risk }\end{array}$ \\
\hline & $\begin{array}{l}\text { Risks and } \\
\text { Opportunities }\end{array}$ & $\begin{array}{l}\text { Identification and management of } \\
\text { strategic risks and opportunities }\end{array}$ & $\begin{array}{l}\text { management, critical } \\
\text { incident risk }\end{array}$ \\
\hline & Management & regarding long-term value creation & $\begin{array}{l}\text { management, business } \\
\text { model resilience }\end{array}$ \\
\hline & $\begin{array}{l}\text { Shareholders' } \\
\text { Rights }\end{array}$ & $\begin{array}{c}\text { Upholding shareholders' concerns } \\
\text { and voices in company strategy } \\
\text { and management }\end{array}$ & $\begin{array}{l}\text { Investment return, voting } \\
\text { rights, information } \\
\text { disclosure }\end{array}$ \\
\hline & $\begin{array}{l}\text { Corporate } \\
\text { Governance }\end{array}$ & $\begin{array}{l}\text { Structure of management system } \\
\text { that reflects the direction and } \\
\text { controlment of the company. }\end{array}$ & $\begin{array}{c}\text { Gender ratio, experiences } \\
\text { of the board members }\end{array}$ \\
\hline & CEO Reputation & $\begin{array}{l}\text { Impact of CEO and top } \\
\text { management personality and } \\
\text { qualifications have on the } \\
\text { corporate image and value }\end{array}$ & $\begin{array}{c}\text { CEO image, management } \\
\text { controversy }\end{array}$ \\
\hline
\end{tabular}

Table A10. Governance factor question items.

\begin{tabular}{ccc}
\hline Measurement Item & Evaluation Scale & Measurement Item \\
\hline Ethical Behavior & 543212345 & $\begin{array}{c}\text { Risks and Opportunities } \\
\text { Management }\end{array}$ \\
\hline Ethical Behavior & 543212345 & Shareholders' Rights \\
\hline Ethical Behavior & 543212345 & Corporate Governance \\
\hline Ethical Behavior & 543212345 & CEO Reputation \\
\hline Risks and Opportunities Management & 543212345 & Shareholders' Rights \\
\hline Risks and Opportunities Management & 543212345 & Corporate Governance \\
\hline Risks and Opportunities Management & 543212345 & CEO Reputation \\
\hline Shareholders' Rights & 543212345 & Corporate Governance \\
\hline Shareholders' Rights & 543212345 & CEO Reputation \\
\hline Corporate Governance & 543212345 & CEO Reputation \\
\hline
\end{tabular}

\section{References}

Agarwal, Upasna A., Sumita Datta, Stacy Blake-Beard, and Shivganesh Bhargava. 2012. Linking LMX, Innovative work behaviour and turnover intentions: The mediating role of work engagement. Career Development International 17: 208-30. [CrossRef]

Aghion, Philippe, Sergei Guriev, and Kangchul Jo. 2021. Chaebols and firm dynamics in Korea. London: Centre for Economic Policy Research. Available online: https:/ / cepr.org/active/publications/discussion_papers/dp.php?dpno=13825 (accessed on 22 July 2021).

Allouche, Jose, and Patrice Laroche. 2005. A meta-analytical examination of the link between corporate social and financial performance. Revue de Gestion des Resources Humaines 57: 18-41.

Amel-Zadeh, Amir, and George Serafeim. 2018. Why and how investors use ESG information: Evidence from a global survey. Financial Anlysts Journal 74: 87-103. [CrossRef]

Becchetti, Leonardo, Rocco Cicretti, Ambrogio Dalo, and Stefano Herzel. 2015. Socially responsible and conventional investment funds: Performance comparison and the global financial crisis. Applied Economics 47: 2541-62. [CrossRef]

Bender, Jennifer, Todd Bridges, Chen He, Anna Lester, and Xioaole Sun. 2018. A Blueprint for Integrating ESG into Equity Portfolios. The Journal of Investment Management 16. Available online: https://papers.ssrn.com/sol3/papers.cfm?abstract_id=3080381 (accessed on 24 July 2021).

Beyond Coal. 2018. Available online: http:/ / beyondcoal.kr/en/ (accessed on 4 July 2021). 
Bhushan, Navneet, and Kanwal Raj. 2004. Strategic Decision Making: Applying the Analytical Hierarchy Process. London: Springer, pp. 11-21.

Boffo, R., and R. Patalano. 2020. ESG Investing: Practices, Progress and Challenges. Paris: OECD. Available online: https://www.oecd. org/finance/ESG-Investing-Practices-Progress-Challenges.pdf (accessed on 24 June 2021).

Boukattaya, Sonia, and Abdelwahed Omri. 2021. Impact of board gender diversity on corporate social responsibility and irresponsibility: Empirical evidence from France. Sustainability 13: 4712. [CrossRef]

Broadstock, David C., Kalok Chan, Louis T. W. Cheng, and Xiaowei Wang. 2021. The role of ESG performance during times of financial crisis: Evidence from COVID-19 in China. Finance Research Letters 38: 101716. [CrossRef]

Brulhart, Franck, Sandrine Gherra, and Bertrand V. Quelin. 2019. Do stakeholder orientation and environmental proactivity impact firm profitability? Journal of Business Ethics 158: 25-46. [CrossRef]

CFA Institute. 2018. ESG Integration in the Americas: Markets, Practices, and Data. Available online: https://www.cfainstitute.org/-/ media/documents / survey/esg-integration-in-the-americas.ashx (accessed on 27 August 2021).

Chen, Chien-Ming, and Magali Delmas. 2011. Measuring Corporate Social Performance: An efficiency perspective. Production and Operations Management 20: 789-804. [CrossRef]

Choi, Mi Hwa. 2015. The effect of corporate social responsibility on the tax aggressiveness and cost of capital. Accounting Information Review 33: 161-93.

Choi, Mi Hwa. 2018. The performance factors of CSR, investment efficiency and firm value. Journal of Finance and Accounting Information 18: 45-66. [CrossRef]

Cornett, Marcia Milon, Otgontsetseg Erhemjamts, and Hassan Tehranian. 2016. Greed or good deeds: An examination of the relation between corporate social responsibility and the financial performance of U.S. commercial banks around the financial crisis. Journal of Banking E Finance 70: 137-59.

De Franco, Carmine. 2020. ESG controversies and their impact on performance. The Journal of Investing 29: 33-45. [CrossRef]

Eccles, Robert G., and George Serafeim. 2013. The Performance Frontier: Innovating for a Sustainable Strategy. Available online: https:/ / www.hbs.edu/faculty/Pages/item.aspx?num=44737 (accessed on 24 July 2021).

Escrig-Olmedo, Elena, María Á. Fernández-Izquierdo, Idoya Ferrero-Ferrero, Juana María Rivera-Lirio, and María Jejús Muñoz-Torres. 2019. Rating the raters: Evaluating how ESG rating agencies integrate sustainability principles. Sustainability 11: 915. [CrossRef]

Felice, Fabio D., Antonella Petrillo, and Claudio Autorino. 2015. Development of a framework for sustainable outsourcing: Analytic Balanced Scorecard Method (A-BSC). Sustainability 7: 8399-419. [CrossRef]

Francis, Jennifer, Allen H. Huang, Shivaram Rajgopal, and Amy Y. Zang. 2008. CEO reputation and earning quality. Contemporary Accounting Research 25: 109-47. [CrossRef]

Freeman, R. E. 1984. Strategic Management: A Stakeholder Approach. New York: Cambridge University Press.

Friede, Gunnar, Timo Busch, and Alexander Bassen. 2015. ESG and financial performance: Aggregated evidence for more than 2000 empirical studies. Journal of Sustainable Finance \& Investment 5: 210-33.

Gallego-Alvarez, Isabel, and Lilane Christina Segura. 2015. Greenhouse gas emissions variation and corporate performance in international companies. International Journal of Global Warming 8: 555-82. [CrossRef]

Gandhi, Sumeet, Sachin Kumar Mangla, Pradip Kumar, and Dinesh Kumar. 2015. Valuating factors in implementation of successful green supply chain management using DEMATEL: A case study. International Strategic Management Review 3: 96-106. [CrossRef]

Garefalakis, Alexandros, and Augustinos Dimitras. 2020. Looking back and forging ahead: The weighing of ESG factors. Annals of Operations Research 294: 151-89. [CrossRef]

Ghassim, Babak, and Marcel Boger. 2019. Linking stakeholder engagement to profitability through sustainability-oriented innovation: A quantitative study of the minerals industry. Journal of Cleaner Production 224: 905-19. [CrossRef]

Goepel, Klaus D. 2013. Implementing the Analytic Hierarchy Process as a standard method for multi-criteria decision making in corporate enterprises-A new AHP Excel template with multiple inputs. Paper presented at International Symposium on the Analytic Hierarchy Process, Kuala Lumpur, Malaysia, June 23-26.

Hart, Stuart L., and Gautam Ahuja. 1996. Does it pay to be green? An empirical examination of the relationship between emission reduction and firm performance. Business Strategy and the Environment 5: 30-37. [CrossRef]

Hazelton, J., and S. Perkiss. 2018. How Useful are CSR Reports for Investors? In Research Handbook of Finance and Sustainability, 1st ed. Edited by Boubaker Sabri, Cumming Douglas and Duc Khuong Nguyen. Cheltenham: Edward Elgar Publishing, Inc., pp. 93-109.

Ho, William, and Xin Ma. 2018. The state-of-the-art integrations and applications of the Analytic Hierarchy Process. European Journal of Operational Research 267: 399-414. [CrossRef]

Hoepner, Andreas G. F., Ioannis Oikonomou, Zacharias Sautner, Laura T. Starks, and Xiao Y. Zhou. 2019. ESG Shareholder Engagement and Downside Risk (Unpublished Working Paper). Available online: https://www.researchgate.net/profile/ Xiaoyan-Zhou-7/publication/318002428_ESG_Shareholder_Engagement_and_Downside_Risk/links/5e6769ce299bf1744f6f1 2f6/ESG-Shareholder-Engagement-and-Downside-Risk.pdf (accessed on 20 June 2021).

Ilhan, Emirhan, Zacharias Sautner, and Grigory Vilkov. 2021. Carbon tail risk. The Review of Financial Studies 34: 1540-71. [CrossRef]

Jang, Jae Young, and Erdal Atukeren. 2019. Sustainable local currency debt: An analysis of foreigners' Korea treasury bonds investments using a LA-VARX model. Sustainability 11: 3603. [CrossRef]

Jang, Jae Young, and Min Jae Park. 2019. A study on global investors' criteria for investment in the local currency bond markets using AHP Methods: The case of the Republic of Korea. Risks 7: 101. [CrossRef] 
Jo, Hoje, and Haejung Na. 2012. Does CSR reduce firm risk? Evidence from controversial industry sector. Journal of Business Ethics 110: 441-56. [CrossRef]

Jost, Lou. 2006. Entropy and diversity. OIKOS 113: 363-75. [CrossRef]

KCGS. 2012. CGS Report. Available online: http:/ / www.cgs.or.kr/CGSDownload/eBook/REP/R002021002.pdf (accessed on 16 June 2021).

Khan, Mozaffar, George Serafeim, and Aaron Yoon. 2017. Corporate sustainability: First evidence on materiality. The Accounting Review 91: 1697-724. [CrossRef]

Kil, Sung-Ho, Dong Kun Lee, Jun-Hyun Kim, Ming-Han Li, and Galen Newman. 2016. Utilizing the Analytic Hierarchy Process to establish weighted values for evaluating the stability of slope revegetation based on hydroseeding applications in South Korea. Sustainability 8: 58. [CrossRef]

Kim, Dae Young, and Sangho Byun. 2016. Influence of corporation-CEO reputation gap on purchase intention, growth prospect, investment attraction, and corporate preference. Asia-Pacific Journal of Business Venturing and Entrepreneurship 11: 131-14.

Kim, Se Jik. 2016. The fall of growth and structural reform in Korea. Seoul Journal of Economics 55: 3-27.

Kim, Sun-Hwa, and Yong-Ki Jung. 2012. The monitoring power of foreign ownership on corporate social responsibility: Evidence from Korea. Korean Accounting Review 37: 1-62.

Kim, Sun-Hwa, and Yong-Ki Jung. 2018. The effects of CSR activities on management risk and information asymmetry, and the differentiated recognition of debtholders: A comparison between large and small-medium companies. Study on Accounting, Taxation \& Auditing 60: 237-74.

Kim, Tae Wan, and Jin Woo Kim. 2018. Differentiative market response of management performance based on the corporate social responsibility activity. Tax Accounting Research 55: 95-114.

Kim, Woo Cheol, and Ji Won Park. 2017. Examining structural relationships between work engagement, organizational procedural justice, knowledge sharing, and innovative work behavior for sustainable organizations. Sustainability 9: 205. [CrossRef]

Lee, Daren, Robert Faff, and Saphira Rekker. 2013. Do high and low-ranked sustainability stocks perform differently? International Journal of Accounting and Information Management 21: 116-32. [CrossRef]

Lee, Yun Sang. 2018. A study on the relationship between corporate social responsibility detailed index and tax avoidance. Tax Accounting Research 57: 55-73.

Matos, Pedro Verga, Victor Barros, and Joaquim Miranda Sarmento. 2020. Does ESG affect stability of dividend policies in Europe? Sustainability 12: 8840.

Menguc, Bulent, and Lucie K. Oanne. 2005. Challenges of the "green imperative": A natural resource-based approach to the environmental orientation-business performance relationship. Journal of Business Research 58: 430-38. [CrossRef]

Ministry of Economy and Finance. 2021. Korea Treasury Bonds 2020. Available online: https://www.moef.go.kr/com/synap/ synapView.do?atchFileId=ATCH_000000000017001\&fileSn=3 (accessed on 25 August 2021).

Moody's. 2021. ESG Issuer Profile and Credit Impact Scores Expanded across More Enterprise, Government Sectors. Available online: https:/ / www.moodys.com/credit-ratings/korea-government-of-credit-rating-440230 (accessed on 25 August 2021).

MSCI. 2020. MSCI ESG Ratings Methodology. Available online: https:/ /www.msci.com/documents/1296102/21901542/MSCI+ESG+ Ratings+Methodology+-+Exec+Summary+Nov+2020.pdf (accessed on 10 June 2021).

Nagy, Zoltan, Linda-Eling Lee, and Guido Giese. 2020. ESG Ratings: How the Weighing Scheme Affected Performance. Available online: https:/ / www.msci.com/www/blog-posts/esg-ratings-how-the-weighting/01944696204 (accessed on 24 July 2021).

Nam, Vu Hoang, Minh Mgoc Nguyen, Duong Anh Nguyen, and Hiep Ngoc Luu. 2020. The impact of corruption on the performance of newly established enterprises: Empirical evidence from a transition economy. Borsa Istanbul Review 20: 383-95. [CrossRef]

National Pension Service. 2021. 2021 ESG Plus Forum: 'Korean-style ESG Investing (23 May 2021). Available online: http:/ / www. koreatimes.co.kr/www/biz/2021/06/175_309245.html (accessed on 25 June 2021).

Noland, Marcus, Tyler Moran, and Barbara R. Kotzchwar. 2016. Is gender diversity profitable? Peterson Institute for International Economics Working Paper. Available online: https:/ / papers.ssrn.com/sol3/papers.cfm?abstract_id=2729348 (accessed on 12 June 2021).

OECD. 2020. OECD Business and Finance Outlook 2020: Sustainable and Resilient Finance. Available online: https://www.oecdilibrary.org/sites/eb61fd29-en/1/3/1/index.html?itemId=/content/publication/eb61fd29-en\&_csp_=648f628b9c3583d125 efc89498a6a043\&itemIGO=oecd\&itemContentType=book\#section-d1e1088 (accessed on 1 June 2021).

Park, Kwang-Hun, and Ju-Seong Lee. 2017. The effect of corporate philanthropy on accounting transparency: Focusing on accrual quality and real activities earnings management. Review of Accounting and Policy Studies 22: 49-80.

Park, Kwong O. 2020. How CSV and CSR affect organizational performance: A productive behavior perspective. International Journal of Environmental Research and Public Health 17: 2556. [CrossRef]

Park, Mi Young. 2017. The effects of corporate governance on corporate social responsibility in China. Korean Computers and Accounting Review 15: 77-99.

Pineiro-Chousa, Juan, Marcos Vizcaíno-González, María Ángeles López-Cabarcos, and Noelia Romero-Castro. 2017. Managing reputational risk through environmental management and reporting: An options theory approach. Sustainability 9: 376. [CrossRef]

Porter, Michael, Serafeim George, and Kramer Mark. 2019. Where ESG Fails. Institutional Investor. Available online: https: //www.institutionalinvestor.com/article/b1hm5ghqtxj9s7/Where-ESG-Fails (accessed on 10 June 2021).

Refinitiv. 2021. ESG Scores Methodology. Available online: https://www.refinitiv.com/content/dam/marketing/en_us/documents/ methodology / refinitiv-esg-scores-methodology.pdf (accessed on 10 June 2021). 
Rehman, Hania, Muhammad Ramzo, Muhammad Zia Ul Haq, Jinsoo Hwang, and Kyoung-Bae Kim. 2021. Risk Management in Corporate Governance Framework. Sustainability 13: 5015. [CrossRef]

S\&P Global. 2021. CSA Companion 2021: Corporate Sustainability Assessment. Available online: https://portal.csa.spglobal.com/ survey/documents/CSA_Companion.pdf (accessed on 10 June 2021).

Saaty, Thomas L. 2003. Decision-making with the AHP: Why is the principal eigenvector necessary. European Journal of Operational Research 145: 85-91. [CrossRef]

Saaty, Thomas L., Paul C. Rogers, and Ricardo Pell. 1980. Portfolio selection through hierarchies. Journal of Portfolio Management 6: 16-21. [CrossRef]

SASB. 2020. SASB Materiality Map. Available online: https:/ / materiality.sasb.org/ (accessed on 21 June 2021).

Sherwood, Matthew W., and Julia Pollard. 2017. The risk-adjusted return potential of integrating ESG strategies into emerging market equities. Journal of Sustainable Finance E Investment 8: 26-44.

Son, Young Hoa. 2012. Prohibit abuse of dominant market position. Inha Law Review 15: 783-818.

Song, Chanhoo, and Seung Hun Han. 2017. Stock market reaction to corporate crime: Evidence from South Korea. Journal of Business Ethics 143: 323-51. [CrossRef]

SustainAbility. 2020. Rate the Raters 2020: Investor Survey and Interview Results. Available online: https:/ /www.sustainability.com/ thinking/rate-the-raters-2020/ (accessed on 19 June 2021).

Swanson, Diane L. 1999. Toward an integrative theory of business and society: A research strategy for corporate social performance. Academy of Management Review 24: 506-21. [CrossRef]

Thakur, Bhanu Pratap Singh, M. Kannadhasan, Parikshit Charan, and C. P. Gupta. 2019. Corruption and firm value: Evidence from emerging market economies. Emerging Markets Finance and Trade 4: 1182-97. [CrossRef]

UNPRI. 2021. PRI Update Q1 2021. Available online: https:/ / www.unpri.org/download?ac=12423 (accessed on 4 July 2021).

Van Duuren, Emiel, Auke Plantinga, and Bert Scholtens. 2016. ESG integration and the investment management process: Fundamental investment reinvented. Journal of Business Ethics 138: 525-33. [CrossRef]

Weber Shandwick. 2018. The CEO Reputation Premium: Gaining Advantage in the Engagement Era. Available online: https://www. webershandwick.com/wp-content/uploads/2018/04/ceo-reputation-premium-infographic.pdf (accessed on 5 July 2021).

Welling, John. 2020. Is South Korea Crowding Your Emerging Markets Allocation? Available online: https://www.indexologyblog. com/2020/11/23/is-south-korea-crowding-your-emerging-markets-allocation/ (accessed on 24 July 2021).

Woo, Min-Chul, and Myoung-Ae Kim. 2015. Trading pattern of institutional investors in Korean stock markets: Analysis by institution type. Journal of Industrial Economics and Business 28: 1109-34.

World Economic Forum. 2020. Measuring Stakeholder Capitalism Towards Common Metrics and Consistent Reporting of Sustainable Value Creation. Available online: https:/ / www.weforum.org/reports/measuring-stakeholder-capitalism-towards-commonmetrics-and-consistent-reporting-of-sustainable-value-creation (accessed on 10 June 2021).

Yang, Hyung Mo, and Tae Hwa Yoon. 2015. A study on investors' evaluation of corporate social responsibility-Using a verification model for value relevance of accounting information. Accounting Information Review 33: 25-52.

Yu, Seungwon. 2013. CEO's political independence, board chair separation, executive's expertise, and performance in state-owned enterprises. KDI Economy Policy 35: 1-39.

Zerfass, Ansgar, Joachim Schwalbach, Gunter Bentele, and Muschda Sherzada. 2014. Corporate communications from the top and from the center: Comparing experiences and expectations of CEOs and communicators. International Journal of Strategic Communication 8: 61-78. [CrossRef] 